\title{
Atlantic salmon (Salmo salar) require increased dietary levels of B-vitamins when fed diets with high inclusion of plant based ingredients
}

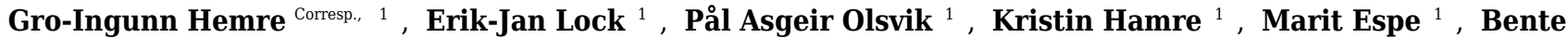 \\ Elisabeth Torstensen ${ }^{1}$, Joana Silva ${ }^{2}$, Ann-Cecilie Hansen ${ }^{1}{ }^{\text {, Rune Waagbø }}{ }^{1}$ ， Johan S Johansen ${ }^{3}$, Monica \\ Sanden ${ }^{1}$, Nini H Sissener ${ }^{1}$ \\ ${ }^{1}$ National Institute of Nutrition and Seafood Research (NIFES), Bergen, Norway \\ 2 Biomar, Trondheim, Norway \\ ${ }^{3}$ GIFAS, Inndyr, Norway \\ Corresponding Author: Gro-Ingunn Hemre \\ Email address: ghe@nifes.no
}

Aiming to re-evaluate current recommendations for nutrient supplementations when Atlantic salmon are fed diets based on plant ingredients, two regression experiments, with parr and post-smolt, were conducted. A control diet was included to evaluate if ingredients supplied sufficient nutrients without any added nutrient package (NP). The nutrient package consisted of vitamins B, C, E, minerals, cholesterol, methionine, taurine and histidine. This paper focus on B-vitamins. In parr, growth, health and welfare parameters responded on NP additions, but this was not observed in the seawater stage. During three months of feeding, parr tripled their weight. Parr given diets added the NP above NRC (2011) showed improved protein retention, and reduced liver and viscera indices. Postsmolt fed the samediets during five months howed a doubling of weight, but did not respond to the variation in NP to the same extent as parr.

Significant regressions were obtained in body compartments for several of the B-vitamins in the premix. Whole body biotin concentration was unaffected by micronutrient premix level, and mRNA expression of the enzymes dependent of biotin showed only weak increases with increased biotin. Muscle thiamine plateaued at a diet level similar to NRC (2011) recommendation in freshwater, and showed stable values independent on premix addition in seawater. The mRNA expression of the enzyme G6PDH (glucose-6-phosphate dehydrogenase) is sensitive to thiamine availability, results did not indicate any need to add thiamine above levels recommended for fish in general. Niacin showed a steady increase in whole body concentrations as feed niacin increased. Muscle riboflavin peaked at a diet level of $12.4 \mathrm{mg} \mathrm{kg}^{-1}$. Sufficient riboflavin is important to avoid e.g. development of cataract. Cataract was not registered to be any problem, neither in fresh- nor in 
seawater. Cobalamin $\left(B_{12}\right)$ in muscle and liver was saturated at $0.17 \mathrm{mg} \mathrm{kg}^{-1}$ diet. Muscle pyridoxine showed a dose-dependent level in muscle, and peaked around $10 \mathrm{mg} \mathrm{kg}^{-1}$ diet. White muscle ASAT (asparagine amino transferase) activity steadily increased, with indications of stable values when dietary pyridoxine was around $10-16 \mathrm{mg} \mathrm{kg}^{-1}$ diet. Pantothenic acid increased in gill tissue up to a level of $5.5 \mathrm{mg} \mathrm{kg}^{-1}$ soft gill tissue; at a dietary level of $22 \mathrm{mg} \mathrm{kg}^{-1}$. Improved performance, and coverage of metabolic need for niacin was at a dietary level of $66 \mathrm{mg} \mathrm{kg}^{-1}$, riboflavin $10-12 \mathrm{mg} \mathrm{kg}^{-1}$, pyridoxine $10 \mathrm{mg}$ $\mathrm{kg}^{-1}$ and panthotenic acid $22 \mathrm{mg} \mathrm{kg}^{-1}$. Based on these results, reccomended B-vitamin supplementation in plant based diets for Atlantic salmon should be adjusted. 
1 Atlantic salmon (Salmo salar) require increased dietary levels of B-vitamins when fed diets with high

2 inclusion of plant based ingredients.

3 G.-I. Hemre ${ }^{1}$, E.J. Lock ${ }^{1}$, P.A.Olsvik ${ }^{1}$, K.Hamre ${ }^{1}$, M.Espe ${ }^{1}$, B.E. Torstensen ${ }^{1}$, J. Silva ${ }^{2}$, A.-C. Hansen ${ }^{1}$, R.

4 Waagb $\varnothing^{1}$, J. Johansen ${ }^{3}$, M.Sanden ${ }^{1} \&$ N.H. Sissener ${ }^{1}$

5

$6 \quad{ }^{1}$ National Institute of Seafood and Nutrition Research (NIFES), Bergen, Norway

$7 \quad{ }^{2}$ Biomar AS, Trondheim, Norway

$8 \quad{ }^{3}$ Gifas AS, Gildeskål, Norway

9

10 Corresponding author:

11 G.-I.Hemre

12 NIFES, Postboks 2029 Nordnes

135817 Bergen, Norway

14 e-mail: ghe@nifes.no

15 phone: (+47) 48185035

16 


\section{Abstract}

Aiming to re-evaluate current recommendations for nutrient supplementations when Atlantic salmon are fed diets based on plant ingredients, two regression experiments, with parr and post-smolt, were conducted. A control diet was included to evaluate if ingredients supplied sufficient nutrients without any added nutrient package (NP). The nutrient package consisted of vitamins B, C, E, minerals, cholesterol, methionine, taurine and histidine. This paper focus on B-vitamins. In parr, growth, health and welfare parameters responded on NP additions, but this was not observed in the seawater stage. During three months of feeding, parr tripled their weight. Parr given diets added the NP above NRC (2011) showed improved protein retention, and reduced liver and viscera indices. Post-smolt fed the same diets during five months showed a doubling of weight, but did not respond to the variation in NP to the same extent as parr.

Significant regressions were obtained in body compartments for several of the B-vitamins in the premix. Whole body biotin concentration was unaffected by micronutrient premix level, and mRNA expression of the enzymes dependent of biotin showed only weak increases with increased biotin. Muscle thiamine plateaued at a diet level similar to NRC (2011) recommendation in freshwater, and showed stable values independent on premix addition in seawater. The mRNA expression of the enzyme G6PDH (glucose-6phosphate dehydrogenase) is sensitive to thiamine availability, results did not indicate any need to add thiamine above levels recommended for fish in general. Niacin showed a steady increase in whole body concentrations as feed niacin increased. Muscle riboflavin peaked at a diet level of $12.4 \mathrm{mg} \mathrm{kg}^{-1}$. Sufficient riboflavin is important to avoid e.g. development of cataract. Cataract was not registered to be any problem, neither in fresh- nor in seawater. Cobalamin $\left(\mathrm{B}_{12}\right)$ in muscle and liver was saturated at $0.17 \mathrm{mg}$ $\mathrm{kg}^{-1}$ diet. Muscle pyridoxine showed a dose-dependent level in muscle, and peaked around $10 \mathrm{mg} \mathrm{kg}^{-1}$ diet. White muscle ASAT (asparagine amino transferase) activity steadily increased, with indications of stable values when dietary pyridoxine was around $10-16 \mathrm{mg} \mathrm{kg}^{-1}$ diet. Pantothenic acid increased in gill tissue up to a level of $5.5 \mathrm{mg} \mathrm{kg}^{-1}$ soft gill tissue; at a dietary level of $22 \mathrm{mg} \mathrm{kg}^{-1}$. Improved performance, and coverage of metabolic need for niacin was at a dietary level of $66 \mathrm{mg} \mathrm{kg}^{-1}$, riboflavin $10-12 \mathrm{mg} \mathrm{kg}^{-1}$, pyridoxine $10 \mathrm{mg} \mathrm{kg}^{-1}$ and panthotenic acid $22 \mathrm{mg} \mathrm{kg}^{-1}$. Based on these results, reccomended B-vitamin supplementation in plant based diets for Atlantic salmon should be adjusted. 
47

\section{Introduction}

Atlantic salmon (Salmo salar) diets with high inclusion of plant ingredients deviate substantially in nutrient composition from diets based on fishmeal. It has been well documented how to balance the amino acid profile and reduce anti-nutritional factors to maintain high growth rates when using high plant protein inclusion diets (Espe et al. 2006; 2007, Krogdahl et al. 2005) and that up to 100\% vegetable oil inclusion does not compromise Altlantic salmon growth when oils are blended to give a balanced fatty acid composition (Torstensen et al. 2005). However, minor attention has been given to micronutrient reccommendations following the shift towards higher levels of plant ingredients.

Both level and form of B-vitamins and some of the indispensable amino acids, are significantly different in plant ingredients and fishmeal (Hansen et al. 2007; 2015). B-vitamins are co-factors in the intermediate metabolism of protein, carbohydrates and lipid, and high concentrations of specific B-vitamins are often present in metabolically active tissues (Waagbø 2010). Previously when fish meal was the main protein source, B-vitamins were in surplus, thus diminishing the consequences of B-vitamin degradation caused by feed production processes. However, since plant protein ingredients contain lower levels of B-vitamins and/or chemical forms with lower bioavailability, knowledge on recommended B-vitamin levels added to feed prior to processing is needed.

Based on available information (Hertrampf \& Piedad-Pascual, 2000; NRC, 2011; Arraina Technical Booklet, pp.23, 2015), the level of riboflavin, vitamin $\mathrm{B}_{12}$ and niacin are low in plant protein materials compared to fishmeal. Corn gluten is low in pantothenic acid and pea meal is low in vitamin $\mathrm{B}_{6}$; all these plant ingredients are readily used in fish diets. In addition, plants are low in methionine and lack taurine Taurineis not regarded an indispensable amino acid, but is present in large quantities in marine feed ingredients and considered important in the prevention of fatty liver in animals (Kerai et al. 1998).

For many of the B-vitamins no recommendations exist for Atlantic salmon. General symptoms for Bvitamin deficiency are reduced growth and appetite (Hansen et al. 2015). Therefore, the reduced growth when salmon was given a high combined plant protein and vegetable oil based diet (Torstensen et al. 2008), might partly be explained by too low levels of several of the B-vitamins, or other components, such as taurine which are absent in plant ingredients (Espe et al., 2016). The accumulation of fat in the liver and around internal organs reported by Torstensen et al. (2011) and Espe and co-workers (2015) when fish meal and fish oil were replaced by high levels of plant ingredients may indicate sub-optimal or deficient levels of micronutrients. This was further supported by Liland et al. $(2013 \mathrm{a}, \mathrm{b})$ who found no difference in lipid deposition in Atlantic salmon fed diets high in plant ingredients when extra micronutrients were added to compensate for the low fish meal and fish oil inclusion. 
79 Generally, early stages of development are considered to be more sensitive to nutrient deficiencies than 80 adult stages, mostly due to fish gut immaturity, rapid growth and development and less vitamin storage 81 capacity. It has therefore been hypothesised that parr in freshwater might need higher levels of some of the 82 B-vitamins than post-smolt held in seawater (Waagbø 2010).

83 In most of the experiments reported in NRC (2011) fish were fed cold-extruded pellets or semi-purified diets, while the extrusion technique used in modern diets use high temperature and pressure and are harsh towards potentially unstable nutrients. Unfortunately, the majority of vitamin B studies published lack the analytical confirmation of the B-vitamin level in feed and organs (NRC, 2011). This is particularily relevant when feed has been produced by modern extrusion, since water soluble vitamins may have been destroyed resulting in a lower dietary level in the final feed (Barrows et al., 2008). For some of the B-vitamins up to $40 \%$ loss was registered (Barrows et al. 2008). Compensating for the processing loss, and ending with levels close to NRC (2011) recommendations, rainbow trout (Oncorhynchus mykiss) responded with improved metabolism and health, but with no effect on growth (Barrows et al. 2008).

This study is part of the larger EU-funded Arraina project where the aim was to establish updated micronutrient recommendations for several aquacultured fish species, including Atlantic salmon, when fed diets with high plant ingredient levels. Here, we report the amino acid and B-vitamin recommendations based on two full regression studies, one with Atlantic salmon parr in freshwater (trial 1), and one with Atlantic salmon post-smolt in seawater (trial 2). Both studies were designed in a dose-response manner with the exact same diet-design, using seven diets with graded levels of a nutrient package (NP) added to a basic diet high in plant ingredients. The rationale was to identify if small freshwater parr and larger seawater post-smolt required a similar nutrient package added to their diets. The NP contained essential vitamins, minerals, cholesterol and amino acids (totally 25 nutrients), where the 100\% NP was close to NRC (2011) recommendations for salmonids (mainly rainbow trout). The inclusion of the NP ranged from no addition to four fold the $100 \%$ addition, and where the $100 \mathrm{NP}$ group represented the current knowledge at the time and NRC (2011) for salmonids. This paper presents updated reccomendations for the B-vitamins biotin, folate, niacin, pantothenic acid, vitamin $\mathrm{B}_{6}$, riboflavin, thiamine and cobalamin plant ingredient based diets for Atlantic salmon.

Data from the same dietary experiments on selected minerals and vitamin A, D and $\mathrm{K}$ related to bone 107 metabolism and on vitamin C, E and selenium related to redox regulation are given in Hamre et al. (2016). 


\section{Materials and methods}

110

111

112

113

114

115

116

117

118

119

120

121

122

123

124

125

126

127

128

129

130

131

132

133

134

135

136

137

138

139

140

\section{Experimental diets}

The seven experimental diets were produced at Biomar Process Innovation Technical Centre (Brande, Denmark) at appropriate pellet sizes to satisfy gape size of salmon parr (2mm) and post-smolts (6mm). Production equipment was modern extrusion, by means of Clextral BC 45, twin screw, 7-sectons, where feed production temperature reached $115^{\circ} \mathrm{C}$. All feed analyses were performed on finished extruded feed, so the values given in Table 1 and 2 are close to similar to the levels given to the fish. All diets contained the same basal mixture of ingredients (Table 1), while a nutrient package (NP) added in graded amounts, replacing some of the field peas. Diets and experimental design were the same in trial 1 with parr in freshwater and trial 2 with post-smolt in seawater. Due to changes in protein and lipid levels between the two size groups; diets in trial 2 held higher lipid and a bit lower protein, these values are given in parenthesis in Table 2. All diets had a low content of marine ingredients, with $8 \% \mathrm{FM}$ and $2.4 \% \mathrm{krill}$ meal (of the total recipe), while the remainder of the protein was provided by plant sources. Capelin oil constituted $20 \%$ of the added oil, while the remainder was a mix of rapeseed oil, palm kernel oil and linseed oil (55:30:15). Phosphate, lysine, threonine and choline were added to all diets in equal amounts. An antioxidant mixture to protect the feed during production, and yttrium for later digestibility measurements were also added to all diets. Diet acronyms were as follows: 0NP had no addition of the micronutrient premix, then the NP was added in graded amounts to the six diets called 25NP, 50NP, 100NP, 150NP, 200NP and 400NP. The general idea was that the $100 \mathrm{NP}$ diets should contain $100 \%$ of the assumed requirement (based on available data, primarily for rainbow trout (NRC, 2011) for each nutrient. The $25 \mathrm{NP}$ would cover $25 \%$ and $400 \mathrm{NP}$ would cover $400 \%$ of earlier estimated requirement for salmonids. However, the accuracy of this will vary between the different nutrients, due to different amounts already provided by the basic ingredients in the feed formulations, in many cases fulfilling much more that $25 \%$ of the assumed requirement. The NP contained vitamin $\mathrm{D}_{3}, \alpha$-tocopherol-acetate, vitamin $\mathrm{K}_{3}$, vitamin $\mathrm{A}_{1}$, ascorbyl monophosphate, vitamin $\mathrm{B}_{6}$, biotin, cobalamin, folate, pantothenic acid, riboflavin, thiamine, niacin, selenium (as inorganic sodium selenite), iodine, copper, cobalt, manganese, zinc, crystalline DL-methionine, and taurine. Crystalline Lhistidine and cholesterol were also added in graded amounts. The analyzed composition of the diets is found in table 2 , including proximate composition and micronutrient content.

\section{Feeding trials}

Both feeding trials were conducted in accordance with Norwegian laws and regulations concerning experiments with live animals, which are overseen by the Norwegian Food Safety Authority. Permission for these specific experiments were given by the Directorate of Fisheries, and accepted for feeding trials 
141 at GIFAS, $\S 13$ (Akvakulturloven) and $\S 28$ a (Lakseforskriften) (ref 13/11363), and acknowlegded by the

142 advisory board 27.11.12 (ref: ARRAINA regression trial permission).

143

144 Trial 1: The trial with parr in freshwater took place at the Institute of Marine Research (Matredal, $61^{\circ} \mathrm{N}$, 145 Western Norway). The salmon were hatched in February, and in June the salmon parr were randomly 146 distributed in fifteen 400 litre $(1 \times 1 \times 0.4 \mathrm{~m})$ experimental tanks, using a flow-through system with $40 \mathrm{~L} \mathrm{~min}^{-}$

147 . The fish was acclimated for 1 week while being fed commercial feed (Skretting ARC, Norway). The 148 trial commenced on July $3^{\text {rd }}$, with duplicate tanks for each diet with the exception of NP100 that was run 149 in triplicates. Each tank contained 100 fish with mean initial body weight of $18.3 \pm 2.2 \mathrm{~g}$ (mean \pm 150 standard deviation (SD)). The fish were fed ad libitum with continuous feeding from automated feeders 151 and a 24h light regime (continuous light). However, care was taken to limit overfeeding, due to 152 uncertainties in the collection of uneaten feed at such a small pellet size. Collection and weighing of 153 uneaten feed was conducted daily at 13:00, with the exception of weekends. The fish were exposed to 154 continuous light, and oxygen saturation was monitored on a regular basis and was never below $75 \%$. The 155 fish were reared in freshwater, but with seawater added as a buffer, creating a salinity of 1.1 to $1.3 \mathrm{~g} \mathrm{~L}^{-1}$. 156 The temperature was kept constant throughout the experiment, at $12.4 \pm 0.7^{\circ} \mathrm{C}$ (mean $\left.\pm \mathrm{SD}\right)$. The total 157 duration of the feeding trial was 12 weeks.

158 Trial 2: Post-smolt Atlantic salmon were randomly distributed among fifteen sea cages $(5 \mathrm{~m} \times 5 \mathrm{~m} \times 5 \mathrm{~m}$; $159125 \mathrm{~m}^{3}$; 150 fish per cage) at Gildesskål Research Station, GIFAS, Gildeskål kommune, Norway. Prior to 160 the start of the trial fish were acclimated to the environmental conditions for two weeks, the feeding trial 161 started in January 2013. As in the freshwater trial, duplicate cages were fed each diet, while the 100NP 162 diet was fed to fish in triplicate cages. At start the mean \pm SD fish weight was $228 \pm 5 \mathrm{~g}$ and during the 163157 day feeding period the fish more than doubled in weight. As in standard aquacultural practice, fish 164 were reared under $24 \mathrm{~h}$ light regime before the start of the trial and during the first 3 months of the 165 experiment. Cages were illuminated by four 400W IDEMA underwater lights that were positioned at the 166 centre of each block of four cages at a depth of three meters. Fish were hand-fed to satiation twice a day 167 and feed intake was recorded for each sea cage. Mortality was recorded daily. Water temperature, salinity 168 and oxygen saturation over the course of the trial varied from 4.1 (January) to $10^{\circ} \mathrm{C}$ (June), $30-34.2 \mathrm{~g} \mathrm{~L}^{-1}$, 169 and 8.7-12.2 $\mathrm{mg} \mathrm{L}^{-1}$, respectively.

170

171 Sampling 
172 Fish were anesthetized (Benzoak ${ }^{\circledR}$ VET, $0.2 \mathrm{ml} / \mathrm{L}$, ACD Pharmaceuticals, Leknes, Norway) and killed by

173 a blow to the head. In addition to bulk weighing of total biomass of the fish in trial 1 (freshwater) at each

174 sampling point, body weight and length were measured on individual fish. Initially 44 fish were sampled

175 before the experiment commenced, thereafter 32 per tank during the experiment ( 5 per tank after 3 weeks,

17622 in the mid sampling after 6 weeks, and 5 after 9 weeks) and 60-68 per tank at the final sampling after 12

177 weeks of feeding (dwarf males were excluded to avoid any bias by gonad production; these were not

178 followed up by any more analyses; the registered number of dwarf males was in total 11 out of a population

179 of 1017, with no difference between tanks or diet groups). The number of fish sampled was based on the

180 following: should be representative for the population in the tank, and should provide enough tissue for all

181 planned analyses. To secure correct amount of feed given according to biomass, a larger number of fish

182 were weighted. All sampling for analyses was performed in the "feeding state" with no starvation before

183 sampling (due to the effect on the GI intestinal morphology, and the focus on amino acids (Espe et al. 2006).

184 (Espe et al. 2006). At the end of trial 1, there were some dwarf males present in all tanks, these were all

185 excluded from tissue sampling and from growth data (fish suspected of being dwarf males were opened to

186 confirm maturing of gonads). In trial 2 (seawater) 44 individual fish were weighed at each sampling. In

187 both trials, blood was drawn from the caudal vessel (Vena caudalis) by means of a heparinized medical

188 syringe from 8 fish per cage, before organs were dissected out and kept as individual samples. Pooled

189 organ samples based on 10 fish for each cage (liver, gills, muscle) were frozen on dry ice and later

190 homogenized, while individual organ samples were flash frozen in liquid nitrogen. Liver weight and gutted

191 weight were recorded (10 fish per cage). Faeces were collected by stripping from the fish used for pooled

192 whole fish samples (10 fish per cage).

193 Chemical analysis of diets, whole fish and organs

194 Moisture was measured by drying at $103^{\circ} \mathrm{C}$ for $24 \mathrm{~h}$, ash weighed after burning at $540^{\circ} \mathrm{C}$ and lipid after

195 extraction with ethyl-acetate in fish tissue, and acid-extraction in fish feed (Lie 1991). Nitrogen was

196 measured with a nitrogen analyzer (Vario Macro Cube, CN, Elementar Analysensysteme GmbH, Hanau,

197 Germany) according to AOAC official methods of analysis (AOAC, 1995), and protein calculated as N x

198 6.25. Starch was measured by enzymatic degradation as described by Hemre et al. (1989). Total amino

199 acids in diets were determined after hydrolysis in $6 \mathrm{~N} \mathrm{HCl}$ at $22^{\circ} \mathrm{C}$ using UPLC (ultra performance liquid

200 chromatography) method as described by Andersen et al. (2013). Free amino acids and nitrogen

201 metabolites in plasma and liver were analyzed using the Biochrome with post column derivatization with

202 ninhydrin as described by Espe et al. (2006). The methyl-donor S-adenosyl methionin (SAM) and S-

203 adenosyl-homocystein (SAH) were determined in liver by HPLC as described (Espe et al. 2008). The B-

204 vitamins biotin, niacin, folate, pantothenic acid and cobalamin were all determined by microbiological 
205

206

207

208

209

210

211

212

213

214

215

216

217

218

219

220

221

222

223

224

225

226

227

228

229

230

231

232

233

234

methods (Feldsine et al. 2002; Mæland et al. 2000). Some of the B-vitamins were determined by HPLC; thiamine (CEN, 2003), vitamin $\mathrm{B}_{6}(\mathrm{CEN}, 2006)$ and riboflavin (Brønstad et al. 2002).

\section{Lipogenic enzyme activity in liver}

Enzyme activity of liver NADH-isocitrate dehydrogenase (ICDH, EC 1.1.1.42), malic enzyme (ME, EC 1.1.1.40), glucose-6-phosphate dehydrogenase (G6PDH, EC 1.1.1.49) and 6-phosphogluconate dehydrogenase (6PGDH, EC 1.1.1.44) was analysed in fish from trial 1 freshwater. The method is described in detail by Sanden (Sanden, 2001). Analysis of total protein were performed on Maxmat Biomedical Analyser (SM1167, Maxmat S.A., France) using Maxmat reagents and the appropriate calibrators, standards and controls for the method. The specific lipogenic enzyme activities are expressed as $\mu \mathrm{mol} \mathrm{min}^{-1} \mathrm{mg}$ protein ${ }^{-1}$.

\section{Haematology, plasma enzymes and nutrients}

Of the pooled blood samples, $200 \mu \mathrm{l}$ were kept as individual samples for haematology, while the remainder was centrifuged at $3000 \mathrm{x} \mathrm{g}$ for $10 \mathrm{~min}$ to obtain the plasma fraction, which was immediately frozen in liquid nitrogen and stored at $-80{ }^{\circ} \mathrm{C}$. Hematocrit (Hct) was immediately measured using Vitex Pari microhaematocrit tubes and a Hettich centrifuge (type 201424). Red blood cells (RBC) and haemoglobin (Hb) were measured on a Cell-Dyn 400 (Sequoia-Turner) according to the manufacturer's instructions, using Para 12 control blood (Streck) for calibration. Plasma ASAT and ALAT (alanine amino transferase), and the indices mean cell volume (MCV), mean cell haemoglobin $(\mathrm{MCH})$ and mean cell haemoglobin concentration (MCHC) were calculated according to Sandnes et al. (1988). Blood smears were prepared at sampling, following the procedure described by Sandnes et al. (1988).

\section{Gene expression analysis}

Total RNA was purified from frozen liver using the EZ1 RNA Universal Tissue Kit on the BioRobot ${ }^{\circledR}$ EZ1 (Qiagen, Hilden, Germany), including the optional DNase treatment step in the protocol.

Homogenisation in QIAzol lysis reagent from the kit was performed on the bead grinder homogeniser Precellys 24 (Bertin Technologies, Montigny-le-Bretonneux, France) for 3x10 sec at 6000rpm. Quantity and quality of RNA were assessed with the NanoDrop ${ }^{\circledR}$ ND-1000 UV-Vis Spectrophotometer (NanoDrop Technologies, Wilmington, DE, USA) and a selection of samples were evaluated on the Agilent 2100 Bioanalyzer (Agilent Technologies, Palo Alto, CA, USA), with the 6000 Nano LabChip ${ }^{\circledR}$ kit (Agilent Technologies, Palo Alto, CA, USA). Average RNA integrity number (RIN) for the samples was $9.4 \pm 01$ (mean $\pm \mathrm{SEM}, \mathrm{n}=11$ ). 
235 Reverse transcription (RT) was performed on a GeneAmp PCR 9700 (Applied Biosystems, AB) using the 236 TaqMan ${ }^{\circledR}$ reverse transcriptase kit with oligo(dT) primers (Applied Biosystems). Primer sequences are

237 given in Table 13. Samples were run in duplicate (500 $\mathrm{ng}, \pm 5 \%$ ), in addition to a six point dilution curve

238 in triplicate (1000 to $31.25 \mathrm{ng}$ ), non-template and non-amplification controls. Real-time PCR

239 amplification and analysis were performed on a LightCycler 480 Real-time PCR system (Roche Applied

240 Science, Basel, Switzerland) with SYBR ${ }^{\circledR}$ Green I Mastermix (Roche Applied Science). Thermal

241 cycling was done for 45 cycles of $10 \mathrm{sec}$ at each of $95^{\circ} \mathrm{C}, 60^{\circ} \mathrm{C}$ and $72^{\circ} \mathrm{C}$ (basic programme from Roche),

242 followed by melting analysis to confirm that only one product is present.

243 Cycle threshold $(\mathrm{Ct})$-values were calculated using the second maximum derivative method in the

244 Lightcycler ${ }^{\circledR}$ software. Normalization to the reference genes (ACTB, EEF1A and UBA52) and data

245 analysis was conducted with the geNorm applet (Vandesomplele et al., 2002).

246 Calculations

247 Condition factor $(\mathrm{K})=\left(\mathrm{bw} / \mathrm{fl}^{3}\right)^{*} 100(\mathrm{bw}=$ body weight, $\mathrm{fl}=$ fork length $)$

248 Organosomatic index $(\%)=(\mathrm{ow} / \mathrm{bw}) * 100(\mathrm{ow}=$ organ weight $)$

249 Specific growth rate $(\% /$ day $)=\left(\ln \mathrm{W}_{\mathrm{f}}-\ln \mathrm{W}_{\mathrm{i}} * 100\right) / \mathrm{t}\left(\mathrm{W}_{\mathrm{f}}=\right.$ final weight, $\mathrm{W}_{\mathrm{i}}=$ initial weight, $\mathrm{t}=$ time in days $)$

250 Thermal growth coefficient $=1000 *\left(\mathrm{~W}_{\mathrm{i}} \wedge 1 / 3-\mathrm{W}_{\mathrm{f}} \wedge 1 / 3\right) / \mathrm{T}^{*} \mathrm{t} \quad(\mathrm{T}=$ temperature $)(\% /$ day adjusted to water

251 temperature)

$252 \mathrm{MCV}=(\mathrm{Hct} / \mathrm{rbc}) * 10$

$253 \mathrm{MCH}=(\mathrm{Hb} / \mathrm{rbc})^{*} 10$

$254 \mathrm{MCHC}=(\mathrm{Hb} / \mathrm{Hct}) * 100$

255 Apparent digestibility coefficient, \% $=100-((\%$ yttriumin feed/ \%yttrium in faeces $) *(\%$ nutrient in faeces/

$256 \%$ nutrient in feed $\left.)^{*} 100\right)$ )

257 Nutrient retention, $\%=[($ final biomass $\times$ final nutrient content $)-($ initial biomass $\times$ initial nutrient content $)]$

$258 \times 100 /($ Total feed intake $\times$ nutrient content in feed $)$

\section{Statistical analyses}

260 All data are given as mean for each diet group and the pooled standard deviation, as most analyses were 261 conducted on pooled samples ( $\mathrm{n}=2$ or $\mathrm{n}=3$ tanks for each dietary group), thus separate standard deviations

262 for each diet group would not be very informative. Regression analyses were conducted in Statistica

263 (Version 11; Statsoft, Tulsa, OK, USA), using tank values (either from pooled samples or tank means for 264 parameters where individual data were available). For each response parameter, an attempt was made to 265 find the best fit model for the data, model comparison was conducted using GraphPad Prism 6. In some 
266

267

268

269

270

271

272

273

274

275

276

277

278

279

280

281

282

283

284

285

286

287

288

289

290

291

292

293

294

295

296

cases, the second order polynomial regression fit the data significantly better than the first order polynomial (straight line). Due to the multi-approach with all nutrients added simultaneously, it was not possible to run regression with analyzed feed level as independent factor for many of the response parameters (such as growth, organ indices, hematology, most amino acids etc). Consequently, the levels 0, 25, 50, 100, 150, 200 and 400 were used. For the nutrients which were fitted with a second order polynomial, the model was used to calculate the feed level at which maximum tissue status would be achieved, thus analyzed feed concentrations rather than $0,25,50$ etc were used for these. In these five cases, the deviation in adjusted $\mathrm{R}^{2}$-values between analysis conducted with actual feed values and $0,25,50$ etc were 3 percentage points on average and it varied which method gave the higher values. Based on this, it was concluded to stick to using $0,25,50$ etc for the other nutrients, as this would make little difference, and the linear regressions could not be used for calculation of recommended feed concentrations of the different nutrients anyway. For regression models, adjusted $\mathrm{R}^{2}$ and $\mathrm{p}$-values are given when the latter is $<0.05$. For the parameters where data on individual fish were available (weight, length, HSI (hepatosomatic index)), (VSI (viscerasomatic index) and K), a nested ANOVA was conducted with diet as fixed factor and tank as random factor, to account for individuals from the same tank being pseudoreplicates.

\section{Results}

\section{Diets}

All diets contained similar amounts of protein, lipid, energy, ash and dry matter (Table 2). There seemed to be a slight gradient in starch content, probably due to the NP replacing field peas in the diet formulation. The added nutrient package generally exhibited a dose-response design, while concentrations of compounds that had not been part of the NP, such as tocopherols other than $\alpha$-tocopherol, vitamin $\mathrm{A}_{2}$, lysine and phytosterols were similar in all seven feeds. Apart from the added nitrogen compounds, amino acid profiles were similar in all feeds (Espe et al. 2014). All diets contained the same oil mixture and fatty acid composition. The marine n-3 fatty acids EPA and DHA constituted $2.5 \%$ of the dietary fatty acids in both trials, but due to increasing dietary lipid content with increasing fish size, this amounted to $3.9 \mathrm{~g} \mathrm{~kg}^{-1}$ feed in trial 1 and $4.8 \mathrm{~g} \mathrm{~kg}^{-1}$ in trial 2 (further data on fatty acid composition are not presented).

\section{Fish performance}

In Trial 1 fish grew from an initial weight of $18.3 \mathrm{~g}( \pm 2.2)$ to a range of $78.6 \mathrm{~g}( \pm 1.9)$ to $87.3 \mathrm{~g}( \pm 4.5)$. Both fish growth and protein retention increased with increasing dietary NP, while lipid retention decreased, together with liver index and viscera-somatic index (Table 3; $<<0.05)$. In trial 2, initial size 
297 was $228 \mathrm{~g}( \pm 4.2)$, and average final weight was $482 \mathrm{~g} \mathrm{(} \pm 17)$. In the seawater trial with post-smolt, there

298 was no effect of the nutrient package on growth or protein and lipid retention (Table 4). Survival was

299 high in both trials, close to $100 \%$, and with no difference between diet groups.

300 In trial 1, linear regression analysis showed that fish growth significantly increased by increasing dietary 301 NP inclusion $\left(\mathrm{R}^{2}=0.48, \mathrm{p}=0.003\right)$ (Table 3$)$. Final weight $\left(\mathrm{R}^{2}=0.49, \mathrm{p}=0.002\right)$ and condition factor $(\mathrm{K}$, $\left.302 \mathrm{R}^{2}=0.70, \mathrm{p}<0.0001\right)$ also increased with increasing NP addition, while length was not affected. Nested 303 ANOVA showed differences between individual diet groups in condition factor (K); fish fed 400NP had 304 higher $\mathrm{K}$ than all other diet groups, while fish fed diet 200NP had significantly higher $\mathrm{K}$ than fish fed $30525 \mathrm{NP}$. For final weight, individual variation was too large to produce significant differences by ANOVA 306 ( $\mathrm{p}=0.13)$. Both hepatosomatic index (HSI, $\left.\mathrm{R}^{2}=0.46, \mathrm{p}=0.03\right)$ and viscerosomatic index (VSI, $\mathrm{R}^{2}=0.48$, $307 \mathrm{p}=0.02$ ) decreased with increasing NP addition. Nested ANOVA showed that HSI was significantly 308 higher in diet group 0NP-100NP, compared to $150 \mathrm{NP}-400 \mathrm{NP}(\mathrm{p}=0.005)$. The same was the case for VSI 309 ( $\mathrm{p}=0.01)$, except $150 \mathrm{NP}$ did not differ significantly from 0NP. In trial 1 there was a pattern for HSI, VSI, 310 SGR and final weight where the four diets with the lowest NP $(0-100 \mathrm{NP})$ had similar values to each 311 other, while the three diets with the most NP $(150 \mathrm{NP}-400 \mathrm{NP})$ also exhibited similar values to each 312 other, with lower organosomatic indices and better growth in the latter three groups. Feed conversion 313 ratios were not significantly affected by diet. Post-smolt held in seawater showed equal SGR and FCR, 314 HSI, VSI and K, so for the larger fish no diet effect during doubling of weight was observed.

315

316

317

318

319

320

321

322

323

324

325

326

327

\section{Haematology and blood smears}

In trial 1 , the only plasma parameter that was significantly affected by diet was ASAT $\left(\mathrm{R}^{2}=0.83\right.$, $\mathrm{p}<0.0001$ ), with higher values when NP inclusion increased (Table 5). The only haematological parameter affected by diet in Trial 1 with small fish was haemoglobin $(\mathrm{Hb})$, increasing with higher NP $\left(\mathrm{R}^{2}=0.25, \mathrm{p}=0.03\right.$, Table 5). In larger salmon (trial 2) hematocrit (Hct, $\left.\mathrm{p}=0.041 \mathrm{R}^{2}=0.2\right)$ and mean cell volume $(\mathrm{MCV})$ responded with increased values as NP increased $\left(\mathrm{p}=0.043, \mathrm{R}^{2}=0.3\right)$ (Table 6).

Blood smears from all groups were investigated and no groups showed any sign of variance between blood cells, or any sign of megaloblastic anemia. The blood smears were visually inspected by means of a microscope (40x enlargement).

\section{Nutrient retention}

Salmon parr held in freshwater responded to increasing NP inclusion with an increase in whole body nitrogen content $\left(\mathrm{R}^{2}=0.48, \mathrm{p}=0.003\right.$, Table 7$)$ and a decrease in whole body lipid content $\left(\mathrm{R}^{2}=0.53\right.$, $\mathrm{p}=0.001)$, the latter was also reflected in a decrease in dry matter $\left(\mathrm{R}^{2}=0.52, \mathrm{p}=0.001\right)$. Protein retention 
328

329

330

331

332

333

334

335

336

337

338

339

340

341

342

343

344

345

346

347

348

349

350

351

352

353

354

355

356

357

358

359

increased with increasing NP $\left(\mathrm{R}^{2}=0.31, \mathrm{p}=0.02\right.$, Table 7). Larger fish held in seawater (trial 2), had similar body composition independent of dietary NP additions (Table 8).

\section{Nutrient status in fish tissues and plasma}

There was no feed deprivation before sampling in any of the tanks / cages. Plasma taurine $\left(\mathrm{R}^{2}=0.66\right.$, $\mathrm{p}=0.0001$, Table 6$)$ and methionine $\left(\mathrm{R}^{2}=0.68, \mathrm{p}<0.0001\right)$ increased with increasing NP addition, glycine and valine, on the other hand, decreased. In muscle, free methionine increased $\left(R^{2}=0.26, p=0.04\right)$ together with glutamic acid $\left(\mathrm{R}^{2}=0.65, \mathrm{p}=0.003\right)$. The other free amino acids and $\mathrm{N}$ metabolites were unaffected by dietary treatment. Although a linear regression model was used for plasma concentrations of the added methionine, histidine and taurine, all of these had the same pattern when data were inspected visually, where they were relatively high in the 0NP diet, then decreased, before increasing again with increasing NP addition in the diet (Table 9; trial 1, and 10 trial 2). No effect of diet was seen on SAH and SAM in liver (Table 9 and 10).

Levels of B-vitamins in fish tissues are given in Tables 7 (trial 1) and Figures 2 (B-vitamins in muscle), 3 (B-vitamins in liver), 4 (B-vitamins in whole body) and 5 (panthotenic acid in gills) for trial 2. Muscle thiamine level in trial 1 and trial 2 was close to similar in all groups (around $0.7 \mathrm{mg} / \mathrm{g}$ wet weight), but with a weak regression dependent on NP diet level ( $\mathrm{p}=0.03$ trial 1 and $\mathrm{p}=0.05$ trial 2) (Figure 2).

Expression of the thiamine dependent G6PD was substantially higher in group fed the 0NP diet compared to the other groups $(\mathrm{p}=0.025)$, while regression analyses showed a weak effect of diet on enzyme activity $(\mathrm{p}=0.025)$ (only measured in trial 1). Muscle tissue thiamine status was also correlated to dietary NP in trial $2\left(\mathrm{R}^{2}=0.45, \mathrm{p}=0.016\right.$ trial 2$)$. Riboflavin showed high correlation to dietary $\mathrm{NP}(\mathrm{R}=0.85, \mathrm{p}=0.00$ in trial 1, but with no significant differences in trial 2; Figure 2). Cobalamin in muscle $\left(R^{2}=0.70, p=0.003\right.$ in trial 1, not measured in trial 2), and in liver $\left(\mathrm{R}^{2}=0.43, \mathrm{p}=0.02\right.$, and $\mathrm{R}^{2}=0.53, \mathrm{p}=0.002$ in trial 2) responded significantly to dietary $\mathrm{B} 12$ in both trials. Liver tissue folate $\left(\mathrm{R}^{2}=0.47, \mathrm{p}=0.003\right.$ in trial 1 , and $\mathrm{R}^{2}=0.42$ $\mathrm{p}<0.01$ in trial 2) increased significantly with the increased NP in diet in both trials. Significant linear regressions were seen in whole fish for niacin $\left(\mathrm{R}^{2}=0.92, \mathrm{p}<0.0001\right)$ in trial 1 , and trial 2. A second order polynomial model was a significantly better fit to the data than linear regression for pyridoxine in whole fish $\left(\mathrm{R}^{2}=0.93, \mathrm{p}<0.0001\right.$ in trial 1 , and $\mathrm{R}^{2}=0.7, \mathrm{p}<0.01$ in trial 2$)$. Biotin in whole fish showed similar levels with no difference in concentrations dependent on diet level, neither in small nor larger salmon. Pantothenic acid in gill soft tissue $\left(\mathrm{R}^{2}=0.95, \mathrm{p}<0.0001\right.$ in trial 1 , and $\mathrm{R}^{2}=0.95, \mathrm{p}<0.001$ in trial 2)

responded significantly to diet levels, in both trials. For these vitamins, the models were used to calculate the feed concentration required to obtain maximum tissue levels, as shown in Figures 2, 3, 4 and 5.

Specific biomarker results 
360 Muscle ASAT was only measured in trial 1, where activated muscle ASAT (with pyridoxine-5-phosphate;

361 P5P) did not respond to variations in dietary inclusion of premix, while the ASAT (not activated) highly

362 correlated with premix inclusion, but with an indication of a plateau at a pyridoxine inclusion level

363 between 8 and $12 \mathrm{mg} \mathrm{kg}^{-1}$ diet (Table 11, Figure 1; trial 1). Liver mRNA expressions of the gene MCC1

364 (methyl crotonyl CoA carboxylase; biotin dependent) did not show any difference between diet groups

365 (Table 12). The two biotin dependent genes PCCA and PCCB (propioyl CoA carboxylase A and B)

366 showed no response for the A form, and a slight but significant regression for the B form. Glucose-6-

367 phosphate dehydrogenase (G6PDH; thiamine dependent) showed high levels in the 0NP group, and then

368 decreased to a more or less stable expression for the 100NP to $400 \mathrm{NP}$ diets (Table 12). For these analyses

369 only trial 1 samples were evaluated. In trial 1 the activity level of enzymes in the pentose-phosphate

370 shunt, 6PGDH (6-phosho-gluconate dehydrogenase, 1.1.1.49; $\mathrm{R}^{2}=0.41, \mathrm{P}=0.01$ ), and G6PDH (glucose-

371 6-phosphate dehydrogenase, 1.1.1.44; $\mathrm{R}^{2}=0.25, \mathrm{p}=0.06$ ) decreased with increasing NP. A similar trend

372 was seen for ME (malic enzyme, EC 1.1.1.39; $\mathrm{R}^{2}=0.21, \mathrm{p}=0.09$ ), while ICDH (iso-citrate-dehydrogenase,

373 EC 1.1.1.42) showed stable values independent of dietary NP (Table 14). These enzyme activities were

374 not measured in trial 2 with post-smolt. 


\section{Discussion}

377 In salmon parr, lower growth and increased K, HSI and VSI in the 0NP-100NP groups, indicate that these

378 diets were deficient in one or several nutrients. Post-smolt Atlantic salmon showed only a weak

379 increased growth when the NP level was above 150NP. The difference between the two trials may have

380 multiple explanations, e.g. parr generally grow faster than post-smolt, further post-smolt showed initial

381 larger nutrient stores, and also water temperature was lower during the post-smolt study compared to the

382 parr study (Espe et al. 2010, Waagbø et al. 2010, Torstensen et al. 2011, NRC 2011).

383 The interpretation of results from our studies must be taken with care, due to the multi-approach with all

384

385

386

387

388

389

390

391

392

393

394

395

396

397

398

399

400

401

402

403

404

405

406 nutrients added simultaneously, there may exist confounding factors that we do not know of. Although the increase in dietary methionine was low, from $7.0-8.5 \mathrm{~g} \mathrm{~kg}^{-1}$ diet in both trials, methionine below the $150 \mathrm{NP}\left(<7.9 \mathrm{~g} \mathrm{~kg}^{-1}\right)$ might have contributed to lower growth and increased HSI, VSI and $\mathrm{K}$, in salmon parr, in agreement with Espe et al. (2014). Post-smolt given low dietary methionine has been found to increase lipid deposition without affecting somatic growth (Espe et al 2008; 2016), however, in our postsmolt study (trial 2) none of these parameters were affected. In earlier studies, a close interaction between methionine and taurine has been identified in parr when given high plant diets added graded levels of methionine and/or taurine, where methionine highly affected taurine liver concentration, in line with Espe et al. (2008). Taurine was identified to affect sulphur metabolism, and to be an efficient antioxidant protecting the liver cells against apoptosis (Espe et al. 2013).

Blood health parameters were within reported normal ranges in both experiments, indicating acceptable fish health in all groups (Sandnes et al. 1988). This was further confirmed also by no incidence of cataract, neither in fresh- nor in seawater, and negliable mortality in both dietary trials. Dietary histidine varied from 10.3 to $13.1 \mathrm{mg} \mathrm{g}^{-1}$, the highest level was expected to significantly protect against cataract development, in accordance with Waagbø (2010) and Remoe et al. (2014). In the present study the lowest dietary histidine did not result in any cataract development, maybe due to limited time on the experimental diets. Higher histidin levels, around $12-14 \mathrm{mg} \mathrm{kg}^{-1}$, are recommended to reduce risk of cataract development in sea (Waagbø, 2010).

In addition to growth, HSI and VSI, B-vitamins requirement can be defined based on body and/or organ concentration saturation together with specific biomarkers for each of the vitamins (Hansen et al. 2015). Dietary vitamin requirement to maintain whole body/tissue saturation is most often higher than the requirement for maximum growth, especially when evaluated during short feeding trials, as also indicated in the present two experiments (Hansen et al. 2015). 
407 The high gene expression of G6PD in the 0NP group might indicate a thiamine dependent metabolic

408 change in this group, since G6PD gene expression may also vary in response to other metabolic

409 adjustments, for example redox regulation, as described in Hamre et al. (submitted 2016). Enzyme

410 activity of G6PDH further confirmed a change in the pentose phosphate activity dependent on NP dose in

411 the diet. This trend was even stronger for the rate-limiting 6PGDH. Both these enzymes participate in the

412 regeneration of NADP+ to NADPH together with $\mathrm{ME}$ and $\mathrm{ICDH}$; however no variation was found for the

413 two latter. As a first precaution, we recommend to add some thiamine to plant based diets; at least above

$4146.2 \mathrm{mg} \mathrm{kg}^{-1}$ as found in the 25NP group. Deficiency signs previously reported for thiamine deficiency,

415 like abnormal swimming, were not observed, as would be expected if thiamine were too low or were

416 broken down e.g. by diet ingredients containing thiaminase, but that would demand raw materials that

417 were of fish origin and which were not subjected to heat (Hansen et al. 2015). With no abnormal

418 swimming observed, the weak regression above the 25NP level we conclude is a response to the dose-

419 response design.

420 Riboflavin deficiency is reported to cause cataract, photophobia and result in short body vertebrae in fish

421 (Waagbø, 2010), none of these deficiency signs were observed in the present study. However, muscle

422 riboflavin increased dependent on dietary riboflavin, up to a diet level around $5 \mathrm{mg} \mathrm{kg}^{-1}$ diet, after which

423 it flattened, indicating that this level is close to fulfilling all metabolic needs for riboflavin, but only in

424 parr. Fish size can influence requirement, which may explain the lack of response in post-smolt. To

425 secure significant riboflavin, we recommend that plant based diets for Atlantic salmon should be added

$4265 \mathrm{mg} \mathrm{kg}^{-1}(50 \mathrm{NP})$, especially in diets for parr.

427 The requirement for vitamin $\mathrm{B}_{6}$ (pyridoxine, pyridoxal and pyridoxamine and their phosphate esters) for

428 growth has been estimated to vary between 2 and $16 \mathrm{mg} \mathrm{kg}^{-1}$ for different fish species (Hansen et al.

429 2015). In the present study no breakpoint was found in muscle $B_{6}$ level, indicating that as high as $10 \mathrm{mg}$

$430 \mathrm{~kg}^{-1}$ might be favorable. This is higher than the $6-8 \mathrm{mg} \mathrm{kg}^{-1}$ diet, based on saturated muscle ASAT

431 activity, as indicated by Albrektsen et al. (1993). In the present study, muscle ASAT was saturated at a

432 dietary $\mathrm{B}_{6}$ level around $10 \mathrm{mg} \mathrm{kg}^{-1}$ diet, both in salmon parr and post-smolt. There is a close relationship

433 between vitamin $\mathrm{B}_{6}$ and protein metabolism shown in studies with Jian carp (Cyprinus carpio var. Jian)

434 by He et al. (2009). They found improved protein productive value (PPV) and reduced plasma ammonia

435 in fish fed a diet supplemented with vitamin $\mathrm{B}_{6}$ compared to control fish. In our study with parr, PPV was

436 improved at a NP inclusion level of $150 \mathrm{NP}$ or higher. Symptoms and consequences of vitamin $\mathrm{B}_{6}$

437 deficiency are many, diverse and severe, and include nervous disorders and abnormal behavior (Hansen et

438 al. 2015). No behavior disorders were observed in the present study, but to secure growth and optimal 
439

440

441 Cobalamin, vitamin $B_{12}$, reached a maximum liver concentration at a diet concentration of $0.17 \mathrm{mg} \mathrm{kg}^{-1}$

protein retention, and saturation of muscle ASAT activity, plant based diets to parr and post-smolt are recommended to contain around $10 \mathrm{mg} \mathrm{kg}^{-1}$ diet $\mathrm{B}_{6}$ or above.

442

443

444

445

446

447

448 similar to what is recommended in NRC (2011). A sign of deficiency would be megaloblastic anemia, characterized by large erythrocytes and white blood cells with fragmented cell nucleus. Often there is a close link to hemoglobin $(\mathrm{Hb})$ when megaloblastic anemia occurs. Hb levels in the present study were all within a normal range for Atlantic salmon (Sandnes et al., 1988; Woodward 1994), although the Hb of parr in freshwater fed the 0NP diet was lower than in the other groups. Blood smears showed that there were no signs of megaloblastic anemia in any of the diet groups. Gut microbiota in warm water fish produce some vitamin $\mathrm{B}_{12}$ (Limsuwan \& Lovell 1981), but even if this took place in the present study (not investigated), salmon diets should still be added vitamin $B_{12}$ in the premix at a level of $0.27 \mathrm{mg} \mathrm{kg}^{-1}$, or higher to saturate body levels, both for parr and post-smolt. No adverse effects were identified at an addition as high as $0.72 \mathrm{mg} \mathrm{kg}^{-1}$. The main function of vitamin $B_{12}$ is when methylcobalamin acts as a coenzyme for methionine synthetase in re-methylation of homocysteine to methionine. This process also involves folate, which is transformed from 5-methyltetrahydrofolate (5-MTHF) to tetrahydrofolate (THF) by methionine synthetase (Ueland and Schneede 2008). THF is important in cell division, thus folate deficiency also lead to megaloblastic anemia (Hansen et al. 2015).

The increase in liver folate when diet levels increased above $1-2 \mathrm{mg} \mathrm{kg}^{-1}$ (requirement according to NRC 2011), is a first indication that Atlantic salmon diets should hold slightly higher folate levels than the present recommendations, when diets are based on plants (Hansen et al. 2015). Folate act as a donor of one-carbon units in several biosynthetic processes. Deficiency result in loss of growth, which was also found in the present study with salmon parr in freshwater, when the NP addition was below 100NP and dietary folate levels below $2.25 \mathrm{mg} \mathrm{kg}^{-1}$. Similar to cobalamin deficiency, too little folate results in hyperirritability, in addition to megaloblastic anemia (Ikeda et al. 1988). Hyperirritability was not observed in our study. No negative effects of folate levels as high as $10 \mathrm{mg} \mathrm{kg}^{-1}$ has ever been seen (Duncan et al. 1993). Folate has been extensively studied in other species in relation to embryo development and cancer (Said et al., 2000). NRC requirements lays between 0.6 and $1.0 \mathrm{mg} \mathrm{kg}^{-1} \mathrm{diet}$ (NRC 2011), in our study and based on the liver levels, folate in Atlantic salmon feeds are recommended to be $3.3 \mathrm{mg} \mathrm{kg}^{-1}$ or higher for both parr and post-smolt.

Tissue status of biotin was not affected by NP addition, showing that even the diet not added any NP, provided sufficient amounts to saturate tissue concentration. Biotin acts as a coenzyme for the carboxylases, e.g. acetyl-coenzyme-A carboxylase (ACCA) and pyruvate carboxylase (PyC), where it 
471 attaches to the amino group of specific lysine residues in these enzymes. Deficiency of biotin often results

472 in damaging of organs, changed behavior and changed skin coloration (Hansen et al. 2015). No such

473 signs were seen in the present studies. However, very low biotin requirement is identified in some fish

474 species, e.g. tilapia (0.05 $\mathrm{mg} \mathrm{kg}^{-1}$; Shiau \& Chin 1999). The feed ingredients provided $0.26 \mathrm{mg}$ biotin per

$475 \mathrm{~kg}$ diet. Expression of PCCA and PCCB (pyrivate carboxylase; two isoforms) in liver confirmed no effect

476 of diet on the transcription level of this enzyme in the present study, except slightly lower expression of

477 PCCB in the 400NP group. This gives good reason to conclude that it is not necessary to add biotin to

478 salmon diets based on the plant ingredients used in this study.

479 Niacin is part of the co-enzymes nicotine adenine dinucleotide (NAD), and NAD phosphate (NADP),

480 transferring $\mathrm{H}+$ and e- in the metabolism of carbohydrates, lipids and amino acids. However, as these are

481 so widely participating in most metabolic reactions, no studies so far indicate that these enzymes can be

482 used as biomarkers for requirement (Hansen et al. 2015). Estimated niacin requirements vary from 7.4 to

$483150 \mathrm{mg} \mathrm{kg}^{-1}$ dry diet (Ng et al., 1997; Halver \& Hardy 2002). Deficiency will result in reduced growth,

484 anorexia, abnormal swimming and haemorrhage, and reduced tissue concentrations. (Hansen et al. 2015).

485 Whole body niacin increased over the whole range of supplementation. This can be translated to a niacin

486 requirement above $400 \mathrm{NP}$ or $110 \mathrm{mg} \mathrm{kg}^{-1}$ dry diet. The significant and steady reduction in PPP-enzyme

487 activity (6PGDH and G6PDH) might further support this. Our recommendation is therefore to add niacin

488 at a level resulting around $65 \mathrm{mg} \mathrm{kg}^{-1}$ in the final diet, to secure growth in Atlantic salmon parr and post-

489 smolt. This level exceeds current recommendations (1-10 $\mathrm{mg} \mathrm{kg}^{-1}$, NRC 2011).

490 Pantothenic acid, vitamin $\mathrm{B}_{5}$, transfers acetyl and acyl groups in energy metabolism. Mitochondria rich

491 cells and cells subjected to high cell division, like gill tissue, are especially sensitive to deficiency of this

492 vitamin (Olsvik et al., 2013). Increased proliferation has been registered in fish fed a diet with no

493 panthotenic acid added, but was not investigated in the present study. Requirement for vitamin $\mathrm{B}_{5}$ for

494 growth are reported from 6-23 $\mathrm{mg} \mathrm{kg}^{-1}$ diet for different fish species (Hansen et al. 2015). The sensitive

495 gill tissue showed a steady increase in vitamin $\mathrm{B}_{5}$ concentration, from 2.3 to $5.9 \mathrm{mg} \mathrm{kg}^{-1}$ tissue, with a very

496 high correlation to diet levels, in agreement with other studies on fish (Hansen et al. 2015). To secure

497 growth and sufficient gill concentrations, we recommend adding Atlantic salmon diets around $22 \mathrm{mg} \mathrm{kg}^{-1}$

498 diet, for both parr and smolt stages, which corresponds to the levels in the $150 \mathrm{NP}$.

\section{Conclusion}

500 The change in diet ingredients where the majority of proteins and lipids come from plants will need

501 adjusted micronutrient premix additions to secure optimal growth and metabolism. Due to faster growth,

502 with a four-fold increase of weight in the parr stage, and doubling of weight in the post-smolt stage, our 
503 data are based on a short period of the production, but indications for both life stages are similar regarding

504 body levels of the B-vitamins. Biotin and thiamine levels were sufficient in plant based diets, as no

505 addition beyond the feed ingredients seemed to be necessary. The other B-vitamins are recommended to

506 be added at or above NRC (2011) recommendations for salmonides to optimise growth, hinder change in

507 liver lipid deposition, and saturate biomarkers specific for each vitamin. Therefore, based on current data

508 updated recommendations for Atlantic salmon parr and post-smolt stages is a diet holding levels of niacin

509 around $65 \mathrm{mg} \mathrm{kg}^{-1}$ diet (current NRC recommendation 1-10mg kg-1, NRC2011), riboflavin 10-12 $\mathrm{mg} \mathrm{kg}^{-1}$

$510 \operatorname{diet}\left(\mathrm{NRC} 2011 ; 4-7 \mathrm{mg} \mathrm{kg}^{-1}\right.$ ), cobalamin 0.17 $\mathrm{mg} \mathrm{kg}^{-1}$ diet (NRC 2011; $0.02 \mathrm{mg} \mathrm{kg}^{-1}$ ), folate $3.3 \mathrm{mg} \mathrm{kg}^{-1}$

511 diet (NRC 2011; 1-2 mg kg-1), pyridoxine 10 $\mathrm{mg} \mathrm{kg}^{-1}$ diet (NRC 2011; 2-16 mg kg-1), and panthotenic acid

$51222 \mathrm{mg} \mathrm{kg}^{-1}$ diet (NRC 2011; $20 \mathrm{mg} \mathrm{kg}^{-1}$ ). Please be aware of confounding effects due to the multi-

513 approach design.

\section{Acknowledgement}

516 The two regression trials was a part of the EU-project ARRAINA; Advanced Research Initiatives for

517 Nutrition and Aquaculture, (7 $7^{\text {th }}$ Framework Programme, FP7-288925, CP-IP Large-scale integrating

518 project). Highly valuated is the technical assistance of Eva Mykkeltvedt (sampling and gene expression

519 analyses), Jacob Wessels (PPP enzyme activity), the staff at the Nutrition department at NIFES,

520 especially Nina Wollertsen and Emilie Lie (B-vitamin analyses), and Anita Birkenes (amino acid

521 analyses). Technical staff at Matre Research Station for fish maintainance of the parr experiment, and

522 Gildeskål for the post-smolt maintenance.

\section{References}

524 Albrektsen S, Waagbø R, Sandnes K. 1993. Tissue vitamin B6 concentrations and asparatate

525 aminotransferase (AspT) activity in Atlantic salmon (Salmo salar) fed graded dietary levels of vitamin

526 B6. Fiskeridirektoratets Skrifter Serie Ernoring. 6: 21- 34.

527 AOAC Official Methods of Analysis 1995. Crude Protein in Meat and Meat Products, Combustion

528 Method, $16^{\text {th }}$ Ed. Metode 992.15 URL: http://www.aoac.org/omarev1/992_15.pdf

529 Feldsine P, Abeyta C, Andrews WH 2002. Journal of AOAC International vol 85, no 5. $1187-1200=$

530 AOAC INTERNATIONAL Methods Committee Guidelines for Validation of Qualitative and

531 Quantitative Food Microbiological Official Methods of Analysis (1996). Journal of AOAC International.

$53285(5)$.

533 Barrows FT, Gaylord TG, Sealey WM, Porter L, Smith CE 2008. The effect of vitamin premix in

534 extruded plant-based and fish meal based diets on growth efficiency and health of rainbow trout,

535 Oncorhunchus mykiss. Aquaculture, 283: 148-155. 
536 Brønstad I, Bjerkås I, Waagbø R 2002. The need for riboflavin supplementation in high and low energy

537 diets for Atlantic salmon Salmo salar L. parr. Aquaculture Nutrition, 8: 209-220.

538 CEN (Comitè Europèen de Normalisation) NS-EN 14122 (2003). Thiamine determination. Foodstuffs -

539 Determination of Vitamin B1 by HPLC.

540 CEN (Comitè Europèen de Normalisation), NS-EN 14663 (2006), Foodstuffs - Determination of vitamin

541 B6 (including its glycosylated forms) by HPLC.

542 Duncan PL, Lovell RT, Butterworth CE, Freeberg LE, Tamura T. 1993. Dietary folate requirement

543 determined for channel catfish, Ictalurus punctatus. Journal of Nutrition, 123: 1888-1897.

544 Kerai MDJ, Waterfield CJ, Kenyon SH, Asker DS, Timbrell JA 1998. Taurine: Protective properties

545 against ethanol induced hepatic steatosis and lipid peroxidation during chronic ethanol consumption in

546 rats. Amino Acids 15 (1-2): 53-76. Doi:10.1007/BF01345280.

547 Espe M, Lemme A, Petri A, El-Mowafi A. 2006. Can Atlantic salmon (Salmo salar) grow on diets devoid

548 of fish meal? Aquaculture, 255: 255-262

549 Espe M, Lemme A, Petri A, El-Mowafi 2007. A Assessment of lysine requirement for maximal protein

550 accretion in Atlantic salmon using plant protein diets. Aquaculture, 263: 168-178

551 Espe M, Hevrøy EM, Liaset B, Lemme A, El-Mowafi A 2008. Methionine intake affect hepatic sulphur

552 metabolism in Atlantic salmon, Salmo salar. Aquaculture 274: 132-141.

553 Espe M, Rathore RM, Du Z-Y, Liaset B, El-Mowafi A. 2010. Methionine limitation results in increased 554 hepatic FAS activity, higher liver 18:1 to 18:0 fatty acid ratio and hepatic TAG accumulation in Atlantic

555 salmon, Salmo salar. Amino Acids: 39: 449-460.

556 Espe M, Holen E 2013. Taurine attenuates apoptosis in primary liver cells isolated from Atlantic salmon.

557 British Joural of Nutrition, 110: 20-28.

558 Espe M, Andersen SM, Holen E, Rønnestad I, Veiseth-Kent E, Zerrahn J-E, Aksnes A 2014. Methionine 559 deficiency does not increase polyamine turnover through depletion of liver S-adenosylmethionine (SAM) 560 in juvenile Atlantic salmon. British Journal of Nutrition, 112: 1274-1283.

561 Espe M, Veiseth-Kent E, Zerrahn J-E, Rønnestad I, Aksnes A. (in press) 2016. Juvenile Atlantic salmon

562 decrease white trunk muscle IGF-1 expression and reduce muscle and plasma free sulphur amino acids

563 when methionine availability is low while liver sulphur metabolites mostly is unaffected by treatment.

564 Aquaculture Nutrition. doi no:10.1111/anu.12294

565 NRC 2011. National Research Council. In: Nutrient Requirement of Fish and Shellfish (Hardy, R.W. ed.), 566 pp. 1-376. National Academy Press, Washington, DC.

567 Halver JE, Hardy RW 2002. The Vitamins. In: Fish Nutrition, Vol. 3 (Halver, J.E. \& Hardy, R.W. eds), 568 pp. 61-141. Elsevier Science, London.

569 Hamre K, Sissener NH, Lock EJ, Olsvik PA, Espe M, Torstensen B, Silva J, Waagbø R, Hemre G-I 2016. 570 Antioxidant nutrition in Atlantic salmon (Salmo salar) parr and smolt, fed diets with high inclusion of 571 plant based ingredients and graded levels of micronutrients and selected amino acids. Submitted. Peer J. 
572 Hansen AC, Rosenlund G, Karlsen Ø, Koppe W, Hemre G-I 2007. Total replacement of fishmeal with

573 plant proteins in diets for Atlantic cod (Gadus morhua L.) I: Effects on growth and protein retention.

574 Aquaculture, 272, 612-624.

575 Hansen A-C, Waagbø R, Hemre G-I 2015. New B vitamin recommendations in fish when fed plant-based

576 diets. Aquaculture Nutrition: 1-21. Doi: 10.1111/anu.12342.

577 He W, Zhou XQ, Feng L, Jiang J, Liu Y 2009. Dietary pyridoxine requirement of juvenile Jian carp

578 (Cyprinus carpiovar. Jian). Aquaculture Nutrition, 15: 402-408.

579 Hertrampf JW, Piedad-Pascual F 2000. Handbook on Ingredients for Aquaculture Feeds. Kluwer

580 Academic Publishers, Dordrecht, The Netherlands.

581 Ikeda S, Ishibashi Y, Murata O, Nasu T, Harada T 1988. Qualitative requirements of the Japanese parrot

582 fish for watersoluble vitamins. Nippon Suisan Gakkaishi, 54: 2029-2035.

583 Krogdahl Å, Hemre G-I, Mommsen TP 2005. Carbohydrates in fish nutrition: digestion and absorption in 584 postlarval stages. Aquaculture Nutrition, 11: 103-122.

585 Lie Ø 1991. Studies on digestion, deposition and fatty acid composition of lipids in cod (Gadus morhua).

$586 \mathrm{PhD}$ thesis, University of Bergen, Bergen, Norway.

587 Liland NS, Espe M, Rosenlund G, Waagbø R, Hjelle JI, Lie Ø, Fontanillas R, Torstensen BE 2013a. High 588 levels of dietary phytosterols affect lipid metabolism and increase liver and plasma triglycerides in

589 Atlantic salmon, Salmo salar L. British Journal of Nutrition, 110(11): 1958-1967.

590 doi:10.1017/S0007114513001347

591 Liland NS, Rosenlund G, Berntssen MHG, Brattelid T, Madsen L, Torstensen BE 2013b. Net production

592 of Atlantic salmon (FIFO; Fish in Fish out $<1$ ) with dietary plant proteins and vegetable oils.

593 Aquaculture Nutrition, 19: 289-300.

594 Limsuwan T, Lovell RT 1981. Intestinal synthesis and absorption of vitamin B12 in channel catfish.

595 Journal of Nutrition, 111: 2125-2132.

596 Mæland A, Rønnestad I, Fyhn HJ, Berg L, Waagbø R 2000. Water-soluble vitamins in natural plankton 597 (copepods) during two consecutive spring blooms compared to vitamins in Artemia franciscana nauplii 598 and metanauplii. Marine Biology, 135 (5): 765-772.

$599 \mathrm{Ng} \mathrm{WK}$, Serrini G, Zhang Z, Wilson RP 1997. Niacin requirement and inability of tryptophan to act as a 600 precursor of $\mathrm{NAD}(+)$ in channel catfish, Ictalurus punctatus. Aquaculture, 152: 273-285.

601 Olsvik P, Hemre G-I, Waagbø R 2013. Exploring early micronutrient deficiencies in rainbow trout 602 (Oncorhynchus mykiss) by next-generation sequencing technology - from black box to functional 603 genomics. PLoS ONE, 8: e69461

604 Remø SC, Hevrøy EM, Olsvik PA, Fontanillas R, Breck O 2014. Dietary histidine requirement to reduce 605 the risk and severity of cataracts is higher than the requirement for growth in Atlantic salmon smolts, 606 independently of the dietary lipid sourc. British Journal of Nutrition, 111: 1759-1772.

607 Said HM, Chattejee N, Haq R, Subramanian VS, Ortiz A, Matherly LH, Sirotnak F, Halsted C 2000. Up608 regulation of intestinal folate uptake pro-chess in dietary folate deficiency: functional and molecular 609 mechanisms. Gastroenterology, 118: A609. 
610 Sanden M 2001. Pentose phosphate activity in liver of Atlantic salmon Salmo salar L. - effects of dietary 611 macronutrient variations and photoperiod. Thesis for the Degree of Candidata Scientiarum, 117. $p$,

612 University of Bergen, Norway.

613 Sandnes K, Lie Ø, Waagbø R 1988. Normal ranges of some blood chemistry parameters in adult farmed 614 Atlantic salmon, Salmo salar. Journal of Fish Biology, 32: 129-136.

615 Shiau SY, Chin YH 1999. Estimation of the dietary biotin requirement of juvenile hybrid tilapia,

616 Oreochromis niloticus x Oaureus. Aquaculture, 170: 71-78.

617 Torstensen B E, Espe M, Sanden M, Stubhaug I, Waagbø R, Hemre G-I, Fontanillas R, Nordgarden U, 618 Hevrøy EM, Olsvik P, Berntssen MHG 2008. Novel production of Atlantic salmon (Salmo salar) protein 619 based on combined replacement of fish meal and fish oil with plant meal and vegetable oil blends.

620 Aquaculture, 285: 193-200.

621 Torstensen B, Espe M, Stubhaug I, Lie Ø 2011. Combined dietary plant proteins and vegetable oil blends 622 increase adiposity and plasma lipids in Atlantic salmon (Salmo salar L.). British Journal of Nutrition, 623 106: 633-647.

624 Vandesomplele V, De Preter K, Pattyn F, Poppe B, Van Roy N, De Paepe A, Speleman F 2002. Accurate 625 normalization of real-time quantitative RT-PCR data by geometric averaging of multiple internal control 626 genes. Genome Biolology, 3, 0034.0031-0034.0012.

627 Waagbø R 2010. Water-soluble vitamins in fish ontogeny. Aquaculture Research, 41: 433-744.

628 Woodward B 1994. Dietary vitamin requirements of cultured young fish, with emphasis on quantitative 629 estimates for salmonids. Aquaculture, 124: 133-168.

630

631 
632 Table 1. Feed formulation trial 1, and trial 2 (given in brackets when deviating from trial 1). Nutrient 633 premix (NP), methionine, taurine and cholesterol were added to the diets in graded amounts, and balanced 634 by reducing the content of field peas in the diets, all other ingredients were used in equal amounts in all 635 diets. Data are in $\mathrm{g} \mathrm{kg}^{-1}$.

\begin{tabular}{l|lllllll}
\hline Composition & ONP & 25NP & 50NP & 100NP & 150NP & 200NP & $400 N P$ \\
\hline $\begin{array}{l}\text { Fish meal SA 68 } \\
\text { superprime }\end{array}$ & 80 & 80 & 80 & 80 & 80 & 80 & 80 \\
Krill meal & 24.2 & 24.2 & 24.2 & 24.2 & 24.2 & 24.2 & 24.2 \\
SPC 60\% & 180 & 180 & 180 & 180 & 180 & 180 & 180 \\
Corn gluten 60 & 40 & 40 & 40 & 40 & 40 & 40 & 40 \\
Pea protein 75 & $124(130)$ & $124(130)$ & $124(130)$ & $124(130)$ & $124(130)$ & $124(130)$ & $124(130)$ \\
Wheat gluten & $180(150)$ & $180(150)$ & $180(150)$ & $180(150)$ & $180(150)$ & $180(150)$ & $180(150)$ \\
Wheat & $61(60)$ & $61(60)$ & $61(60)$ & $61(60)$ & $61(60)$ & $61(60)$ & $61(60)$ \\
Field peas & 100 & 98 & 95 & 90 & 85 & 80 & 60 \\
Fish oil, capelin & $35(44)$ & $35(44)$ & $35(44)$ & $35(44)$ & $35(44)$ & $35(44)$ & $35(44)$ \\
Rapeseed oil & $79(88)$ & $79(88)$ & $79(88)$ & $79(88)$ & $79(88)$ & $79(88)$ & $79(88)$ \\
Linseed oil & 22 & 22 & 22 & 22 & 22 & 22 & 22 \\
Palm kernel oil & $44(48)$ & $44(48)$ & $44(48)$ & $44(48)$ & $44(48)$ & $44(48)$ & $44(48)$ \\
Histidine & 0.00 & 0.34 & 0.68 & 1.36 & 2.04 & 2.72 & 5.44 \\
DL methionine & 0.00 & 0.13 & 0.25 & 0.51 & 0.76 & 1.02 & 2.04 \\
Taurine & 0.00 & 0.61 & 1.22 & 2.45 & 3.67 & 4.90 & 9.80 \\
Minerals & 0.00 & 0.03 & 0.06 & 0.12 & 0.17 & 0.23 & 0.47 \\
Water soluble & 0.00 & 0.01 & 0.03 & 0.06 & 0.09 & 0.12 & 0.24 \\
vitamins & & & & & & & \\
Fat soluble vitamins & 0.00 & 0.03 & 0.06 & 0.12 & 0.17 & 0.23 & 0.46 \\
Cholesterol & 0.00 & 0.28 & 0.56 & 1.13 & 1.69 & 2.25 & 4.50 \\
\hline
\end{tabular}

636 *all diets were added $38 \mathrm{~g} \mathrm{~kg}^{-1}$ monosodium phosphate, mineral additions were adjusted to each nutrient 637 package. All diets were added $9.3 \mathrm{~g} \mathrm{~kg}^{-1}$ lysine, $1.8 \mathrm{~g} \mathrm{~kg}^{-1}$ threonin, $8 \mathrm{~g} \mathrm{~kg}^{-1}$ choline (50\%), $0.25 \mathrm{~g} \mathrm{~kg}^{-1}$ 638 barox becp dry. Detailed composition for the B-vitamins are given in Table 2. 
639 Table 2. Analysed feed and nutrient composition. All results are the mean of two analytical parallels.

640 Protein, lipid, starch ash and dry matter are given in $\mathrm{g} \mathrm{kg}^{-1}$, while all other diet components are given as $641 \mathrm{mg} \mathrm{kg}^{-1}$. Slight difference in macronutrient composition; trial 2 is given in parenthesis. For the 642 micronutrients in diets forboth experiements were similar.

\begin{tabular}{|c|c|c|c|c|c|c|c|}
\hline & ONP & $25 N P$ & $50 N P$ & 100NP & 150NP & 200NP & 400NP \\
\hline \multicolumn{8}{|c|}{ Proximate composition, $\mathrm{g} \mathrm{kg}^{-1}$} \\
\hline Protein & $453(480)$ & $469(472)$ & $449(440)$ & $456(480)$ & $462(480)$ & $470(480)$ & $461(480)$ \\
\hline Lipid & $213(220)$ & $203(220)$ & $219(210)$ & $211(230)$ & $208(220)$ & $197(240)$ & $195(220)$ \\
\hline Starch & 112 & 112 & 109 & 104 & 106 & 107 & 94 \\
\hline Ash & 66 & 68 & 66 & 67 & 69 & 60 & 75 \\
\hline Dry matter & $910(950)$ & $930(940)$ & $920(930)$ & $920(930)$ & 930 & $920(930)$ & 920 \\
\hline $\begin{array}{l}\text { Energy, joule } \\
\mathrm{kg}^{-1}\end{array}$ & 22.8 & 22.7 & 22.6 & 22.7 & 22.4 & 22.5 & 22.0 \\
\hline \multicolumn{8}{|c|}{ Micronutrients and other dietary components, $\mathrm{mg} \mathrm{kg}^{-1}$} \\
\hline Vitamin $\mathrm{B}_{6}$ & 2.6 & 3.2 & 4.0 & 5.2 & 7.1 & 10.0 & 16.0 \\
\hline Biotin & 0.25 & 0.28 & 0.31 & 0.40 & 0.57 & 0.70 & 1.14 \\
\hline Cobalamin & 0.07 & 0.06 & 0.10 & 0.17 & 0.30 & 0.39 & 0.69 \\
\hline Folate & 1.18 & 1.17 & 1.58 & 2.25 & 3.28 & 4.20 & 7.23 \\
\hline $\begin{array}{l}\text { Pantothenic } \\
\text { acid }\end{array}$ & 6.5 & 7.5 & 9.9 & 16 & 25 & 31 & 54 \\
\hline Riboflavin & 2.7 & 3.2 & 4.7 & 6.8 & 10 & 13 & 20 \\
\hline Thiamine & 3.4 & 4.2 & 5.0 & 6.2 & 8.3 & 11 & 16 \\
\hline Niacin & 36 & 36 & 41 & 50 & 64 & 76 & 110 \\
\hline Vitamin C & $<5.5$ & 14 & 28 & 63 & 89 & 140 & 170 \\
\hline $\begin{array}{l}\text { Methionine } \\
\mathrm{g} \mathrm{kg}^{-1}\end{array}$ & 6.99 & 7.01 & 7.17 & 7.29 & 7.86 & 8.08 & 8.49 \\
\hline Histidine $\mathrm{g} \mathrm{kg}^{-1}$ & 10.5 & 10.4 & 11.0 & 11.3 & 12.3 & 12.4 & 13.2 \\
\hline Taurine $\mathrm{g} \mathrm{kg}^{-1}$ & 0.70 & 1.20 & 1.79 & 3.10 & 3.90 & 5.27 & 5.92 \\
\hline Lysine ${ }^{1} \mathrm{~g} \mathrm{~kg}^{-1}$ & 29.7 & 31.2 & 28.1 & 28.4 & 29.5 & 28.6 & 31.0 \\
\hline
\end{tabular}

$643{ }^{1}$ As a representative of the amino acids that were not varied between the diets (either added to all diets in 644 equal amounts or only provided naturally by the diet ingredients). 
646 Table 3. Performance parameters and organ weights trial 1 with parr in freshwater. Mean and pooled SD. 647 Regression analysis is conducted on tank means ( $n=2$ per diet group, and $n=3$ for $100 N P$ ). $K=$ condition 648 factor, HSI= hepatosomatic index, VSI = viscerosomatic index. Nested ANOVA was conducted for the 649 parameters where individual data was available.

\begin{tabular}{|c|c|c|c|c|c|c|c|c|c|}
\hline & ONP & $25 N P$ & $50 N P$ & 100NP & 150NP & 200NP & 400NP & $\begin{array}{l}\text { Pooled } \\
\text { SD }\end{array}$ & Regression \\
\hline SGR & 1.75 & 1.75 & 1.74 & 1.75 & 1.82 & 1.82 & 1.86 & 0.04 & $\begin{array}{l}R^{2}=0.48, \\
p=0.003\end{array}$ \\
\hline $\begin{array}{l}\text { TGC, } \\
\text { total }\end{array}$ & 1.60 & 1.60 & 1.58 & 1.60 & 1.69 & 1.68 & 1.73 & 0.04 & $\begin{array}{l}R^{2}=0.48, \\
p=0.003\end{array}$ \\
\hline $\begin{array}{l}\text { Final } \\
\text { weight }\end{array}$ & 79.7 & 79.6 & 78.6 & 79.7 & 84.6 & 84.2 & 87.3 & 2.5 & $\begin{array}{l}R^{2}=0.49 \\
p=0.002\end{array}$ \\
\hline Length & 19.5 & 19.5 & 18.2 & 18.4 & 18.7 & 18.6 & 18.7 & 0.7 & n.s. \\
\hline $\mathrm{K}$ & $1.28^{\mathrm{AB}}$ & $1.26^{\mathrm{A}}$ & $1.28^{\mathrm{AB}}$ & $1.28^{\mathrm{AB}}$ & $1.29^{\mathrm{AB}}$ & $1.30^{\mathrm{B}}$ & $1.34^{C}$ & 0.01 & $\begin{array}{l}R^{2}=0.70 \\
p<0.0001\end{array}$ \\
\hline FCR & 0.86 & 0.83 & 0.82 & 0.83 & 0.85 & 0.78 & 0.81 & 0.02 & n.s. \\
\hline $\mathrm{HSI}$ & $1.53^{\mathrm{A}}$ & $1.60^{\mathrm{A}}$ & $1.56^{\mathrm{A}}$ & $1.65^{\mathrm{A}}$ & $1.31^{\mathrm{B}}$ & $1.25^{\mathrm{B}}$ & $1.25^{\mathrm{B}}$ & $0.07^{B}$ & $R^{2}=0.46, p=0.03$ \\
\hline VSI & $11.6^{\mathrm{AB}}$ & $11.9^{\mathrm{A}}$ & $11.9^{\mathrm{A}}$ & $11.9^{\mathrm{A}}$ & $10.8^{\mathrm{BC}}$ & $10.6^{c}$ & $10.5^{C}$ & 0.31 & $\mathrm{R}^{2}=0.48, p=0.02$ \\
\hline
\end{tabular}

650 Initial weight $18.3(2.2)$ g, length $11.4(0.5) \mathrm{cm}, \mathrm{K} 1.23(0.04)$, HSI $1.20(0.32)$, VSI 14.8 (1.5), all as mean \pm sd for 44 fish (15 for 651 the organ indices).

652

653 Table 4. Performance parameters and organ weights trial 2 with post-smolt in seawater. Mean and pooled 654 SD. Regression analysis is conducted on means for each cage ( $n=2$ per diet group, and $n=3$ for $100 \mathrm{NP}$ ). $655 \mathrm{P} 1=$ period 1; week 0 to $6, \mathrm{P} 2=$ period 2; week 6 to 12 . $\mathrm{K}=$ condition factor, HSI= hepatosomatic index, 656 VSI = viscerosomatic index. Nested ANOVA was conducted for the parameters where individual data 657 was available.

\begin{tabular}{|c|c|c|c|c|c|c|c|c|c|}
\hline & ONP & $25 N P$ & $50 N P$ & 100NP & 150NP & 200NP & 400NP & $\begin{array}{l}\text { Pooled } \\
\text { SD }\end{array}$ & Regression \\
\hline SGR & 0.47 & 0.50 & 0.48 & 0.50 & 0.50 & 0.48 & 0.50 & 0.02 & n.s. \\
\hline TGC & 2.37 & 2.53 & 2.42 & 2.52 & 2.53 & 2.46 & 2.55 & 0.10 & n.s. \\
\hline $\begin{array}{l}\text { Initial } \\
\text { weight }\end{array}$ & 224 & 229 & 230 & 227 & 229 & 228 & 231 & 4.2 & n.s. \\
\hline $\begin{array}{l}\text { Final } \\
\text { weight }\end{array}$ & 459 & 487 & 480 & 480 & 492 & 478 & 496 & 17 & n.s. \\
\hline Length & 34 & 34 & 34 & 35 & 36 & 34 & 37 & 2 & \\
\hline $\mathrm{K}$ & 1.21 & 1.36 & 1.19 & 1.09 & 1.01 & 1.18 & 1.00 & 0.2 & n.s. \\
\hline FCR & 0.99 & 0.98 & 0.99 & 0.97 & 0.97 & 0.99 & 0.97 & 0.02 & n.s. \\
\hline $\mathrm{HSI}$ & 7.80 & 7.99 & 7.86 & 8.18 & 7.81 & 7.59 & 7.84 & 0.41 & n.s. \\
\hline VSI & 1.34 & 1.42 & 1.37 & 1.33 & 1.46 & 1.31 & 1.32 & 0.07 & n.s. \\
\hline
\end{tabular}

658 Initial mean weight $228 \pm 4 \mathrm{~g}$, mean \pm sd for 44 fish. 
661 Table 5. Haematology of fish fed the experimental diets during the parr freshwater stage (trial 1), with 662 one pooled sample of blood/plasma from 8 fish analysed per tank at the main sampling. $\mathrm{RBC}=\mathrm{red}$ blood 663 cell count, $\mathrm{Hct}=$ hematocrit, $\mathrm{MCV}=$ mean cell volume, $\mathrm{MCH}=$ mean cell haemoglobin, $\mathrm{MCHC}=$ mean cell 664 haemoglobin concentration.

\begin{tabular}{|c|c|c|c|c|c|c|c|c|c|}
\hline & ONP & $25 N P$ & 50NP & 100NP & 150NP & 200NP & 400NP & $\begin{array}{l}\text { Pooled } \\
\text { SD }\end{array}$ & Regression \\
\hline $\mathrm{Hb}$ & 9.05 & 9.15 & 8.80 & 9.13 & 9.25 & 9.15 & 9.40 & 0.15 & $\begin{array}{l}R^{2}=0.25 \\
p=0.03\end{array}$ \\
\hline RBC & 1.27 & 1.32 & 1.30 & 1.31 & 1.27 & 1.28 & 1.29 & 0.04 & n.s. \\
\hline Hct & 42.5 & 42.5 & 41.5 & 41.7 & 43.0 & 42.0 & 43.0 & 0.6 & n.s. \\
\hline $\mathrm{MCV}$ & 335 & 322 & 319 & 319 & 340 & 330 & 335 & 9 & n.s. \\
\hline $\mathrm{MCH}$ & 71.3 & 69.3 & 67.7 & 70.0 & 73.3 & 71.9 & 73.2 & 1.9 & n.s. \\
\hline $\mathrm{MCHC}$ & 21.3 & 21.5 & 21.2 & 21.9 & 21.5 & 21.8 & 21.9 & 0.4 & n.s. \\
\hline
\end{tabular}

665

666

667

668

669

670

671

672

\begin{tabular}{|c|c|c|c|c|c|c|c|c|c|}
\hline & ONP & $25 N P$ & $50 N P$ & $100 N P$ & 150NP & $200 N P$ & 400NP & $\begin{array}{l}\text { Pooled } \\
\text { SD }\end{array}$ & Regression \\
\hline $\mathrm{Hb}$ & 9.4 & 9.0 & 9.2 & 8.9 & 9.1 & 9.1 & 9.6 & 0.4 & n.s. \\
\hline $\mathrm{RBC}$ & 0.35 & 1.30 & 1.29 & 1.32 & 1.31 & 1.29 & 1.35 & 0.03 & n.s. \\
\hline Hct & 39 & 37 & 38 & 38 & 38 & 38 & 40 & 1.6 & $\mathrm{R}^{2}=0.2 \mathrm{p}=0.041$ \\
\hline MCV & 289 & 281 & 291 & 286 & 290 & 294 & 299 & 9 & $R^{2}=0.3 p=0.043$ \\
\hline $\mathrm{MCH}$ & 69 & 69 & 71 & 68 & 70 & 70 & 71 & 2 & n.s. \\
\hline $\mathrm{MCHC}$ & 24 & 25 & 24 & 24 & 24 & 24 & 24 & 1 & n.s.- \\
\hline
\end{tabular}

Table 6. Heamatology of fish fed the experimental diets during the post-smolt seawater stage (trial 2), with one pooled sample of blood/plasma from 8 fish analyzed cage at the main sampling. Abbreviations, see Table 5 .

Initial values at the start sampling: het 38.0 (1.7), rbc 1.19 (0.07), hg 8.13 (0.31), MCV 319 (8), MCH 68.3 (3.4), MCHC 21.4 (1.1), all as mean (sd) of three analyzed samples, each sample pooled from 5 fish.

The 5 
675 Table 7. Proximate analyses and nutrient retention from trial 1 with parr in freshwater, homogenized 676 pooled whole fish samples of 10 fish per tank, ( $n=2$ per diet group, and $n=3$ for 100NP). Data are 677 presented as mean \pm pooled $\mathrm{sd}$, proximate analyses in $\mathrm{g} \mathrm{kg}^{-1}$.

\begin{tabular}{|c|c|c|c|c|c|c|c|c|c|}
\hline & $\begin{array}{l}\mathrm{ON} \\
\mathrm{P}\end{array}$ & $25 N P$ & $50 N P$ & 100NP & 150NP & 200NP & 400NP & $\begin{array}{l}\text { Pooled } \\
\text { SD }\end{array}$ & Regression \\
\hline \multicolumn{10}{|c|}{ Proximate analyses $\left(g \mathrm{~kg}^{-1}\right)$} \\
\hline Lipid & 132 & 129 & 131 & 129 & 127 & 117 & 119 & 2.7 & $R^{2}=0.53, p=0.001$ \\
\hline Protein & 175 & 180 & 175 & 180 & 175 & 185 & 190 & 3.9 & $R^{2}=0.43, p=0.005$ \\
\hline Ash & 23.3 & 23.6 & 21.2 & 24.5 & 19.8 & 23.3 & 22.8 & 2.2 & n.s. \\
\hline $\begin{array}{l}\text { Dry } \\
\text { matter }\end{array}$ & 330 & 330 & 330 & 330 & 320 & 325 & 320 & 2.0 & $R^{2}=0.52, p=0.001$ \\
\hline \multicolumn{10}{|c|}{ Nutrient retention (\%) } \\
\hline Protein & 45.4 & 47.1 & 48.2 & 48.8 & 45.0 & 52.3 & 52.5 & 2.1 & $\mathrm{R}^{2}=0.31, \mathrm{p}=0.02$ \\
\hline Lipid & 78.0 & 82.0 & 78.5 & 79.9 & 76.9 & 79.6 & 78.6 & 3.4 & n.s. \\
\hline
\end{tabular}

678 Initial levels before the start of the trial (analyzed on triplicate samples, each consisting of 5 pooled fish), mean with SD in 679 parenthesis: lipid $102(3)$, protein 170 (0), ash $22.1(0.5)$, dry matter 285 (1).

680

681 Table 8. Proximate analyses and nutrient retention from trial 2 with postsmolt in seawater, homogenized 682 pooled whole fish samples of 10 fish per cage, $(n=2$ per diet group, and $n=3$ for $100 \mathrm{NP})$. Data are 683 presented as mean \pm pooled sd, proximate analyses in $\mathrm{g} \mathrm{kg}^{-1}$.

\begin{tabular}{|c|c|c|c|c|c|c|c|c|c|}
\hline & ONP & $25 N P$ & $5 N P$ & 100NP & 150NP & 200NP & 400NP & $\begin{array}{l}\text { Pooled } \\
\text { SD }\end{array}$ & $\begin{array}{l}\text { Regres } \\
\text { sion }\end{array}$ \\
\hline \multicolumn{10}{|c|}{ Proximate analyses $\left(\mathrm{g} \mathrm{kg}^{-1}\right)$} \\
\hline Lipid & 89 & 97 & 95 & 96 & 90 & 83 & 96 & 17 & n.s. \\
\hline Protein & 180 & 195 & 190 & 190 & 195 & 195 & 190 & 9.6 & n.s. \\
\hline Ash & 20 & 18 & 20 & 19 & 19 & 20 & 21 & 1.7 & n.s. \\
\hline $\begin{array}{l}\text { Dry } \\
\text { matter }\end{array}$ & 293 & 301 & 299 & 296 & 296 & 288 & 297 & 4.9 & n.s. \\
\hline \multicolumn{10}{|c|}{ Nutrient retention (\%) } \\
\hline Protein & 33.1 & 41.0 & 41.1 & 38.4 & 40.6 & 39.7 & 38.4 & 4.9 & n.s. \\
\hline Lipid & 43.2 & 51.0 & 51.6 & 48.2 & 45.2 & 33.9 & 50.0 & 6.6 & n.s. \\
\hline
\end{tabular}


687

688 Table 9. Free amino acids and N-metabolites in plasma ( $\mu \mathrm{mol} / \mathrm{dl})$ and liver $(\mu \mathrm{mol} / \mathrm{g})$ of Atlantic salmon 689 fed the seven experimental diets, analyzed on pooled samples of 8 fish per tank for plasma and 10 fish per 690 tank for liver, 2-3 tanks per diet group. Values are given as diet group means, and the pooled standard 691 deviation is given. Results are from parr in freshwater (Trial 1).

\begin{tabular}{|c|c|c|c|c|c|c|c|c|c|}
\hline & ONP & $25 N P$ & 50NP & $100 N P$ & 150NP & 200NP & 400NP & $\begin{array}{l}\text { Pooled } \\
\text { SD }\end{array}$ & Regression \\
\hline \multicolumn{10}{|c|}{ Free amino acids and $\mathrm{N}$-metabolites in plasma $(\mu \mathrm{mol} / \mathrm{dl})$} \\
\hline TAU & 61.8 & 49.9 & 56.7 & 71.8 & 77.5 & 82.4 & 88.2 & 3.9 & $\begin{array}{l}R^{2}=0.66 \\
p=0.0001\end{array}$ \\
\hline GLY & 26.3 & 23.5 & 24.3 & 24.8 & 23.7 & 18.7 & 18.7 & 1.9 & $\begin{array}{l}R^{2}=0.46 \\
p=0.003\end{array}$ \\
\hline VAL & 54.7 & 53.4 & 48.9 & 45.2 & 46.4 & 43.9 & 43.7 & 4.1 & $\begin{array}{l}R^{2}=0.25 \\
p=0.03\end{array}$ \\
\hline HIS & 10.9 & 8.8 & 8.7 & 9.0 & 9.3 & 10.3 & 11.1 & 0.9 & n.s. $(p=0.13)$ \\
\hline ARG & 12.2 & 9.4 & 11.4 & 11.4 & 13.5 & 13.4 & 13.2 & 1.3 & n.s. $(p=0.08)$ \\
\hline \multicolumn{10}{|c|}{ Free amino acids and $N$-metabolites in liver $(\mu \mathrm{mol} / \mathrm{g})$} \\
\hline TAU & 15.7 & 16.0 & 16.8 & 18.1 & 17.4 & 15.3 & 17.9 & 1.06 & n.s. \\
\hline PEA & 0.22 & 0.23 & 0.23 & 0.22 & 0.21 & 0.19 & 0.19 & 0.01 & $\begin{array}{l}R^{2}=0.42, \\
p=0.008\end{array}$ \\
\hline OH-PRO & 0.15 & 0.16 & 0.11 & 0.09 & 0.09 & 0.09 & 0.09 & 0.02 & $\begin{array}{l}R^{2}=0.27 \\
p=0.03\end{array}$ \\
\hline THR & 0.87 & 1.04 & 0.93 & 0.86 & 0.79 & 0.81 & 0.73 & 0.07 & $\begin{array}{l}R^{2}=0.45 \\
p=0.005\end{array}$ \\
\hline SER & 1.59 & 1.86 & 1.67 & 1.44 & 1.40 & 1.42 & 1.27 & 0.10 & $\begin{array}{l}R^{2}=0.47 \\
p=0.004\end{array}$ \\
\hline GLU & 7.38 & 7.41 & 7.67 & 7.63 & 8.11 & 8.22 & 9.04 & 0.36 & $\begin{array}{l}R^{2}=0.65 \\
p=0.0003\end{array}$ \\
\hline GLN & 4.53 & 4.79 & 4.80 & 4.10 & 4.35 & 3.91 & 3.91 & 0.32 & $\begin{array}{l}R^{2}=0.22, \\
p=0.05\end{array}$ \\
\hline PRO & 1.26 & 1.50 & 1.26 & 1.17 & 1.16 & 1.14 & 1.06 & 0.08 & $\begin{array}{l}R^{2}=0.34 \\
p=0.02\end{array}$ \\
\hline MET & 0.34 & 0.37 & 0.33 & 0.33 & 0.35 & 0.42 & 0.42 & 0.03 & $\begin{array}{l}R^{2}=0.26 \\
p=0.04\end{array}$ \\
\hline HIS & 0.76 & 0.78 & 0.78 & 0.71 & 0.75 & 0.72 & 0.80 & 0.04 & n.s. \\
\hline \multicolumn{10}{|c|}{ Liver methyl donors (nmol/g ww) } \\
\hline SAH & 24.4 & 23.5 & 25.2 & 21.9 & 19.6 & 26.3 & 21.0 & 2.4 & n.s. \\
\hline SAM & 40.3 & 30.1 & 35.6 & 33.2 & 37.2 & 40.3 & 40.2 & 4.1 & n.s. \\
\hline
\end{tabular}

692 Tau=taurine, $\mathrm{gly}=$ glycine, $\mathrm{val}=$ =valine, his=histidine, arg=arginine, $\mathrm{pea}=$ phosphoethanolamine, $\mathrm{OH}-\mathrm{pro}-$ 693 hydroxyl-proline, thr=threonine, ser=serine, glu=glutamine, gln=glutamic acid, pro=proline,

694 met=methionine, HIS = one-methylhistidine, SAH- S-Adenyhomocysteine, SAM- S-adenosyl695 methionine. 
697 Table 10. Free amino acids and N-metabolites in plasma ( $\mu \mathrm{mol} / \mathrm{dl})$ and liver $(\mu \mathrm{mol} / \mathrm{g})$ of Atlantic salmon 698 fed the seven experimental diets, analyzed on pooled samples of 8 fish per tank for plasma and 10 fish per 699 tank for liver, 2-3 tanks per diet group. Values are given as diet group means, and the pooled standard 700 deviation is given. Results are from smolt in seawater (Trial 2).

\begin{tabular}{|c|c|c|c|c|c|c|c|c|c|}
\hline & ONP & $25 N P$ & 50NP & $100 N P$ & 150NP & $200 N P$ & 400NP & $\begin{array}{c}\text { Pooled } \\
\text { SD } \\
\end{array}$ & Regression \\
\hline \multicolumn{10}{|c|}{ Free amino acids $(\mu \mathrm{mol} / \mathrm{g})$} \\
\hline TAU & 3.3 & 6.4 & 11.5 & 49.2 & 57.3 & 47.2 & 57.9 & 3.3 & $\begin{array}{l}R^{2}=0.51 \\
p=0.0016\end{array}$ \\
\hline THR & 18.4 & 17.0 & 17.0 & 15.2 & 14.5 & 12.6 & 15.2 & 0.8 & $\begin{array}{l}R^{2}=-0.21, \\
p=0.048\end{array}$ \\
\hline SER & 25.1 & 24.9 & 22.6 & 19.5 & 16.7 & 14.0 & 14.3 & 0.5 & $\begin{array}{l}R^{2}=-0.71, \\
p<0.001\end{array}$ \\
\hline GLN & 53.9 & 50.7 & 40.3 & 39.5 & 38.8 & 28.0 & 34.9 & 1.7 & $\begin{array}{l}R^{2}=-0.41 \\
p=0.006\end{array}$ \\
\hline PRO & 88.9 & 84.6 & 84.3 & 61.4 & 63.4 & 46.4 & 49.3 & 8.3 & $\begin{array}{l}R^{2}=-0.46 \\
p=0.003\end{array}$ \\
\hline GLY & 94.3 & 84.6 & 86.2 & 68.9 & 66.4 & 50.6 & 50.4 & 3.0 & $\begin{array}{l}R^{2}=-0.71 \\
p=0.001\end{array}$ \\
\hline Citrulline & 6.4 & 6.4 & 7.0 & 11.7 & 101. & 13.5 & 17.7 & 2.2 & $\begin{array}{l}R^{2}=0.48 \\
p=0.002\end{array}$ \\
\hline AABA & 0.8 & 0.7 & 0.7 & 0.9 & 1.6 & 1.2 & 1.4 & 0.2 & $R^{2}=023, p=0.04$ \\
\hline VAL & 59.9 & 56.7 & 51.7 & 48.5 & 52.9 & 38.8 & 43.5 & 2.0 & $\begin{array}{l}R^{2}=-0.44 \\
p=0.004\end{array}$ \\
\hline LEU & 53.0 & 47.5 & 47.3 & 48.6 & 49.4 & 38.0 & 42.7 & 2.3 & $\begin{array}{l}R^{2}=-0.26 \\
p=0.03\end{array}$ \\
\hline TYR & 29.9 & 27.0 & 20.6 & 21.1 & 14.3 & 14.5 & 14.2 & 2.8 & $\begin{array}{l}R^{2}=-0.45 \\
p=0.004\end{array}$ \\
\hline PHE & 18.2 & 16.9 & 15.9 & 18.0 & 15.8 & 14.3 & 14.8 & 0.8 & $\begin{array}{l}R^{2}=-0.24, \\
p=0.04\end{array}$ \\
\hline Ornitine & 4.7 & 3.6 & 3.4 & 2.2 & 3.1 & 2.0 & 2.0 & 0.3 & $\begin{array}{l}R^{2}=0.35 \\
p=0.011\end{array}$ \\
\hline ARG & 13.5 & 11.4 & 12.1 & 10.0 & 12.0 & 8.9 & 9.2 & 1.1 & $\begin{array}{l}R^{2}=-0.25 \\
p=0.03\end{array}$ \\
\hline \multicolumn{10}{|c|}{ Liver methyl donors $(\mu \mathrm{mol} / \mathrm{g})$} \\
\hline SAH & 25.7 & 24.2 & 26.4 & 18.0 & 17.9 & 18.2 & 18.9 & 4.4 & n.s. \\
\hline SAM & 56.0 & 38.4 & 52.3 & 23.9 & 19.7 & 24.1 & 17.7 & 16.4 & n.s. \\
\hline
\end{tabular}

701 Tau=taurine, thr=threonine, ser $=$ serine, gln=glutamic acid, pro=proline, gly=glycine, beta-ala=bala-beta-

702 alanine, aaba=alpha aminobuturic acid, val=valine, leu=leucine, tyr=tyroxine, phe=phenylanalnine, arg=arginine, SAH- S-Adenyhomocysteine, SAM- S-adenosyl-methionine. 
705

706 Table 11. Tissue vitamin status trial 1 ( $\mathrm{mg} \mathrm{kg}^{-1}$ wet weight), analyzed on homogenized pooled samples of 70710 fish per tank, ( $n=2$ per diet group, and $n=3$ for $100 \mathrm{NP}$ ). Data are presented as mean \pm pooled sd. The 708 column called "Regression" gives $\mathrm{R}^{2}$ and $\mathrm{p}$-values for linear ( $\left(1^{\text {st }}\right.$ order polynomial) regressions, or for 709 second order polynomial regressions where this provided a significantly better fit to the data. Trial 1 in 710 freshwater.

\begin{tabular}{|c|c|c|c|c|c|c|c|c|c|}
\hline & ONP & $25 N P$ & $50 N P$ & 100NP & 150NP & 200NP & 400NP & $\begin{array}{l}\text { Pooled } \\
\text { SD }\end{array}$ & Regression* \\
\hline \multicolumn{10}{|l|}{ Whole fish } \\
\hline Biotin & 0.081 & 0.076 & 0.078 & 0.076 & 0.075 & 0.080 & 0.079 & 0.003 & n.s. \\
\hline Niacin & 24.0 & 24.5 & 27.0 & 31.0 & 36.5 & 46.0 & 54.5 & 1.7 & $R^{2}=0.92, p<0.0001$ \\
\hline \multicolumn{10}{|c|}{ Muscle tissue } \\
\hline Thiamine & 0.70 & 0.65 & 0.65 & 0.77 & 0.75 & 0.70 & 0.80 & 0.04 & $R^{2}=0.27, p=0.03$ \\
\hline $\mathrm{B}_{6}$ & 1.65 & 1.75 & 2.25 & 3.70 & 4.30 & 5.25 & 6.15 & 0.39 & $R^{2}=0.92, p<0.0001$ \\
\hline $\mathrm{B}_{12}$ & 0.033 & 0.020 & 0.033 & 0.045 & 0.047 & 0.049 & 0.052 & 0.004 & $R^{2}=0.63, p=0.003$ \\
\hline Riboflavin & 0.85 & 0.8 & 1.15 & 1.17 & 1.05 & 1.25 & 1.00 & 0.06 & $R^{2}=0.85, p=0.000$ \\
\hline \multicolumn{10}{|l|}{ Liver tissue } \\
\hline Folate & 10.8 & 9.6 & 11.1 & 11.6 & 10.5 & 13.5 & 12.9 & 0.5 & $R^{2}=0.46, p=0.005$ \\
\hline $\mathrm{B}_{12}$ & 0.40 & 0.41 & 0.41 & 0.47 & 0.45 & 0.48 & 0.45 & 0.02 & $R^{2}=0.34, p=0.02$ \\
\hline \multicolumn{10}{|c|}{ Gill soft tissue } \\
\hline $\mathrm{B}_{5}$ & 2.60 & 2.30 & 2.95 & 4.07 & 5.50 & 5.25 & 5.90 & 0.19 & $R^{2}=0.94, p<0.0001$ \\
\hline
\end{tabular}


713 Table 12. Liver mRNA expression of genes dependent on B-vitamins as co-factors in metabolism; only 714 selected groups were analysed. MCC1 (Methyl crotonyl coA carboxylase: biotin dependent), PCCA 715 (propioyl CoA carboxylase-A and propionyl CoA carboxylase-B; biotin dependent), G6PD Glucose-6716 phosphate dehydrogenase (thiamine dependent). Only trial 1 was analysed.

\begin{tabular}{|c|c|c|c|c|c|c|}
\hline & 0NP & $100 \mathrm{NP}$ & $200 \mathrm{NP}$ & 400NP & $\begin{array}{l}\text { Pooled } \\
\text { SD }\end{array}$ & Regression* \\
\hline $\mathrm{MCC1}$ & 0.412 & 0.422 & 0.396 & 0.398 & 0.116 & n.s. \\
\hline G6PD & 0.706 & 0.246 & 0.394 & 0.311 & 0.264 & $\mathrm{R}^{2}=0.14 . \mathrm{p}=0.025$ \\
\hline PCCA & 0.482 & 0.369 & 0.459 & 0.397 & 0.125 & n.s. \\
\hline PCCB & 0.423 & 0.381 & 0.424 & 0.308 & 0.101 & $\mathrm{R}^{2}=0.15 . \mathrm{p}=0.017$ \\
\hline
\end{tabular}


719 Table 13. RT-qPCR assays used, including gene names, accession numbers, primer sequences, amplicon 720 sizes and PCR efficiencies.

\begin{tabular}{|c|c|c|c|c|c|c|}
\hline Gene & Full gene name & Accession/Contig no. & Forward primer & Reverse primer & $\begin{array}{l}\text { Amplicon } \\
\text { size (bp) }\end{array}$ & $\begin{array}{c}\text { PCR } \\
\text { efficiency }\end{array}$ \\
\hline MCC1 & $\begin{array}{l}\text { Methylcrotonoyl-CoA } \\
\text { carboxylase subunit alpha, } \\
\text { mitochondrial precursor }\end{array}$ & Unigene882_A.salmon & TCCTCCATCATCTGCCATCA & GGAGCTTCTCATCCGATTGG & 122 & 192 \\
\hline & Glucose-6-phosphate & & & & & \\
\hline G6PD & dehydrogenase & Contig7869_A.salmon & GCCGTCTACGCCAAGATGAT & TCGGGCAACTTCACATCCTT & 110 & 2.08 \\
\hline PCCA & $\begin{array}{l}\text { Propionyl CoA Carboxylase, } \\
\text { Alpha Polypeptide }\end{array}$ & Unigene11719_A.salmon & GCTGAAGGCCAGGAGATCTG & TCCAACCGTCTCTCCTGCTT & 114 & 2.16 \\
\hline & $\begin{array}{l}\text { Propionyl-CoA carboxylase } \\
\text { beta chain, mitochondrial- }\end{array}$ & Contig4808_A._salmon & CCGTCCCCAAGATCACCAT & CAGAAGGCCAGGCGTAGTTC & & \\
\hline PCCB & like & & & & 105 & 2.16 \\
\hline АСТВ* & Beta-actin & BG933897 & CCAAAGCCAACAGGGAGAA & AGGGACAACACTGCCTGGAT & 92 & 2.00 \\
\hline & Eukaryotic translation & & & & & \\
\hline EEF1AB* & elongation factor 1 alpha B & BG933853 & TGCCCCTCCAGGATGTCTAC & CACGGCCCACAGGTACTG & 57 & 2.03 \\
\hline & Ubiquitin A-52 Residue & & & & & \\
\hline & Ribosomal Protein Fusion & & & & & \\
\hline UBA52* & Product 1 & NM_001141291 & CCAATGTACAGCGCCTGAAA & CGTGGCCATCTTGAGTTCCT & 110 & 2.04 \\
\hline
\end{tabular}


723 Table 14. Liver 6-phosphogluconate dehydrogeanse (6PGDH), glucose-6-phosphate dehydrogeanse

724 (G6PDH), malic enzyme (ME) and NADP-isocitrate dehydrogeanse (ICDH) activity ( $\mu \mathrm{mol} \mathrm{min}^{-1} \mathrm{mg}$

725 protein $^{-1}$ ) from trial 1 with parr. With one pooled sample of liver from 8 fish analysed per cage. Data are

726 presented as mean \pm pooled $\mathrm{sd}(\mathrm{n}=2$ per diet group, and $\mathrm{n}=3$ for $100 \mathrm{NP})$. Regression analysis is conducted

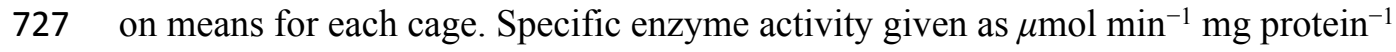

\begin{tabular}{|l|l|l|l|r|r|r|r|r|l|}
\hline & 1NP & \multicolumn{1}{l|}{ 25NP } & 50NP & $100 \mathrm{NP}$ & $150 \mathrm{NP}$ & 200NP & 400NP & $\begin{array}{l}\text { Pooled } \\
\text { SD }\end{array}$ & Regression \\
\hline 6PGDH & 0.114 & 0.116 & 0.119 & 0.108 & 0.108 & 0.108 & 0.081 & 0.017 & $\mathrm{R}^{2}=0.41, \mathrm{p}=0.01$ \\
\hline G6PDH & 0.260 & 0.180 & 0.166 & 0.206 & 0.141 & 0.137 & 0.112 & 0.074 & $\mathrm{R}^{2}=0.25, \mathrm{p}=0.06$ \\
\hline ME & 0.333 & 0.331 & 0.356 & 0.330 & 0.325 & 0.403 & 0.380 & 0.039 & $\mathrm{R}^{2}=0.21, \mathrm{p}=0.09$ \\
\hline ICDH & 0.270 & 0.320 & 0.274 & 0.284 & 0.301 & 0.320 & 0.274 & 0.036 & $\mathrm{~ns}$ \\
\hline
\end{tabular}

728 


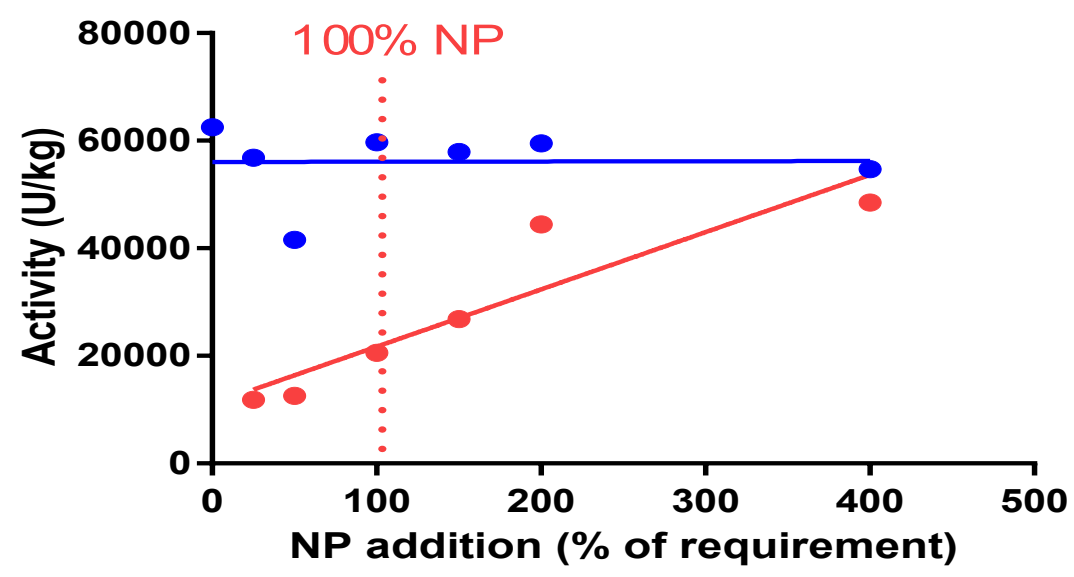

$\rightarrow$ Activated

- Not activated

Figure 1. Activity of asparatate amino transferase (ASAT) in muscle of salmon fed diets with increasing levels of the nutrient package (defined in Table 2). The enzyme was activated or not by adding

735 pyridoxine-5-phosphate in the assay buffer. The points for not activated ASAT were fitted to a first- and second order polynomial and the first order polynomial was preferred $\left(p=0.14, p=0.01 ; R^{2}=0.85\right)$. 

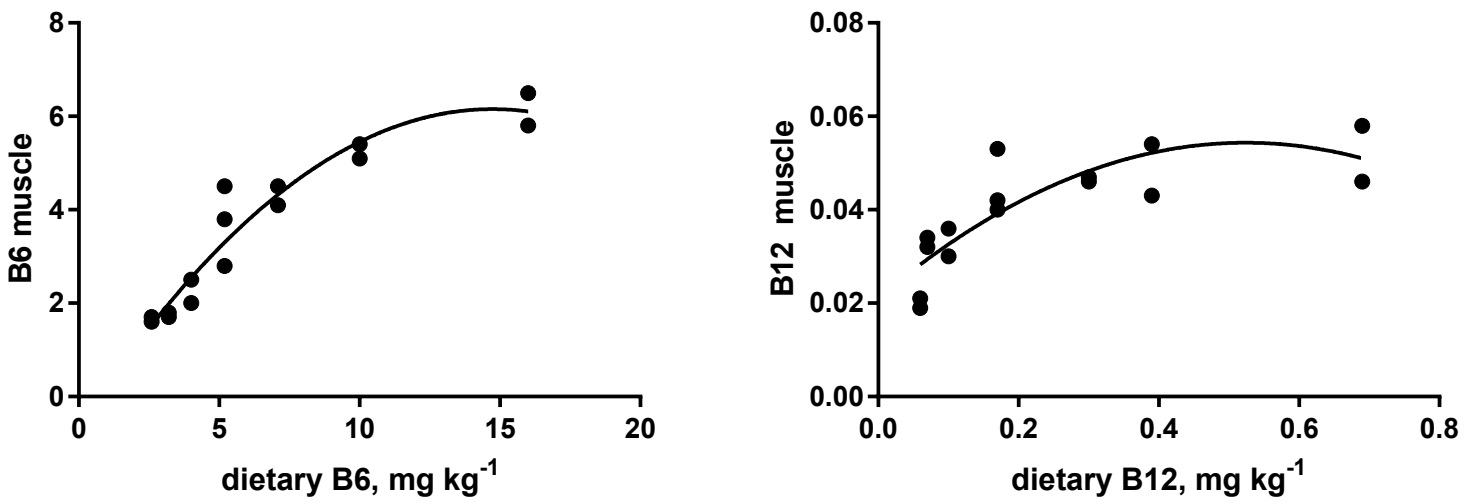

741

742
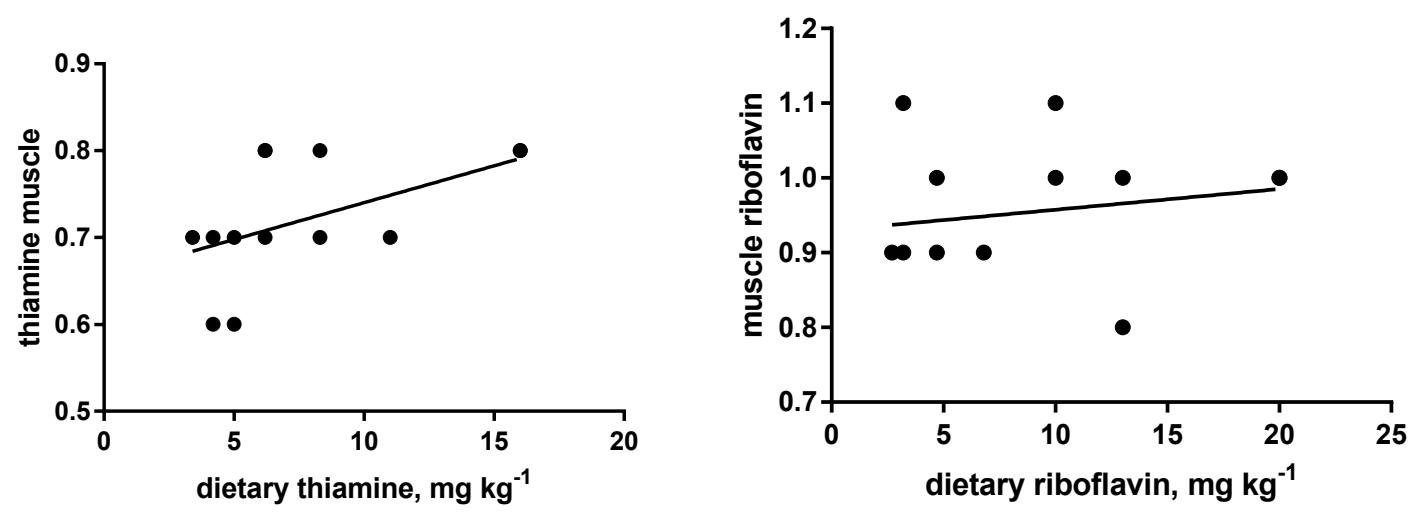

744 Figure 2. Upper left) B6, pyridoxine in muscle ( $\mathrm{mg} \mathrm{kg}^{-1}$ on $\mathrm{y}$-axis): $\mathrm{p}=0.007, \mathrm{R}^{2}=0.92$; second order 745 polynomial. Upper right) $\mathrm{B} 12$, cobalamin in muscle ( $\mathrm{mg} \mathrm{kg}^{-1}$ on $\mathrm{y}$-axis), dietary B12 on $\mathrm{x}$-axis; $\mathrm{p}<0.01$,

$746 \mathrm{R}^{2}=0.7$, second order polynomial. Lower left) thiamine in muscle ( $\mathrm{mg} \mathrm{kg}^{-1}$ on y-axis), and dietary

747 thiamine ( $x$-axis); $p=0.05, R^{2}=0.27$ : linear regression. Lower right) riboflavin in muscle ( $\mathrm{mg} \mathrm{kg}^{-1}$ on $y$-axis),

748 and dietary riboflavin ( $x$-axis); not significant. 

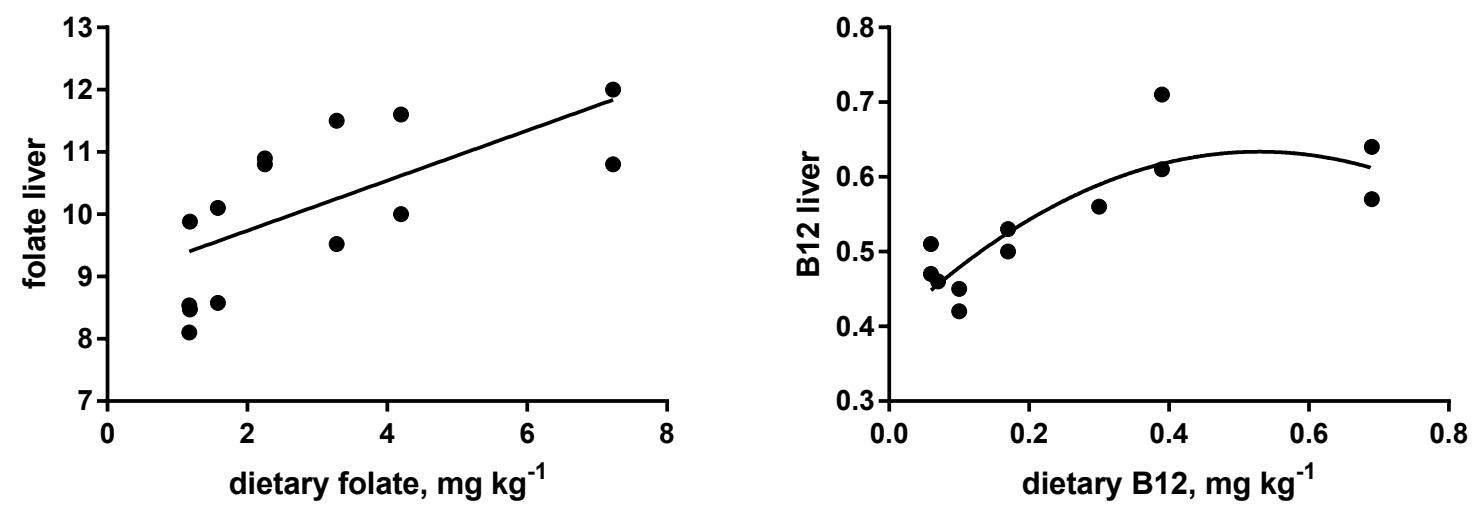

751 Figure 3. Left) folate in liver ( $y$-axis, $\mathrm{mg} \mathrm{kg}^{-1}$ ), and in diet ( $x$-axis); $p<0.01, \mathrm{R}^{2}=0.42$; linear regression.

752 Right) B12 (cobalamin) in liver ( $y$-axis, $\mathrm{mg} \mathrm{kg}^{-1}$ ), and dietary B12 ( $\mathrm{x}$-axis); $\mathrm{p}<0.01, \mathrm{R}^{2}=0.75$, second order 753 polynomial. 

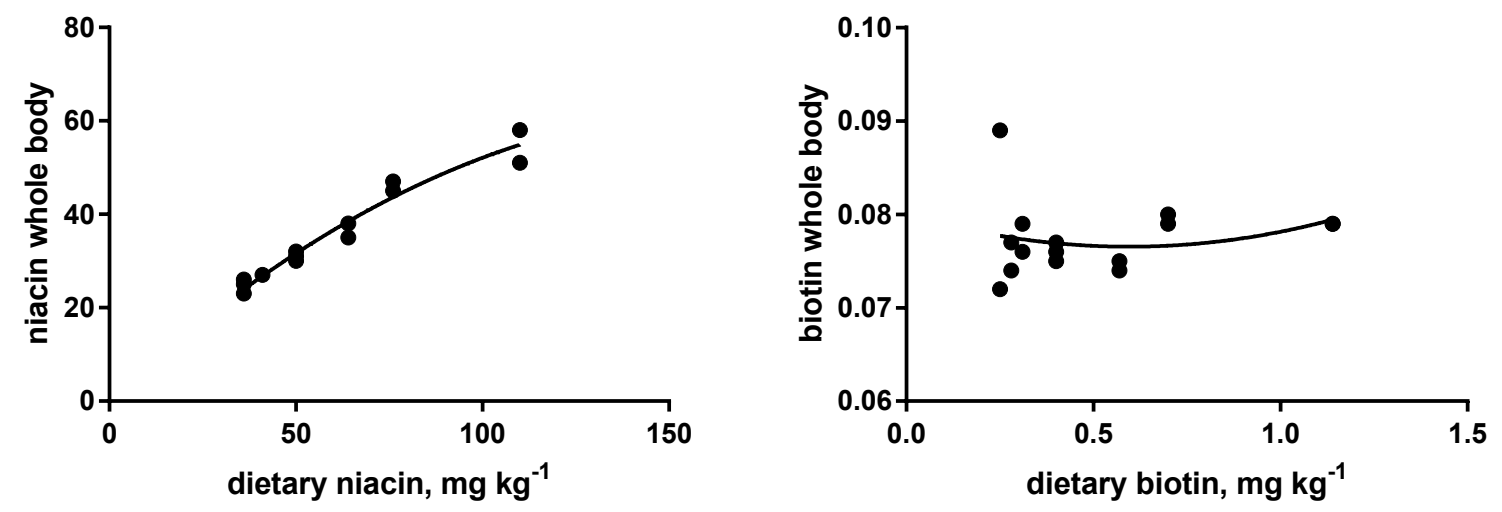

757 Figure 4. Left) niacin in whole body ( $y$-axis, $\mathrm{mg} \mathrm{kg}^{-1}$ ), and $x$-axis levels in feed; $p=0.001, R^{2}=0.95$ : linear 758 regression. Right) biotin in whole body (y-axis, $\mathrm{mg} \mathrm{kg}^{-1}$ ), and diet levels (x-axis); not significant. 


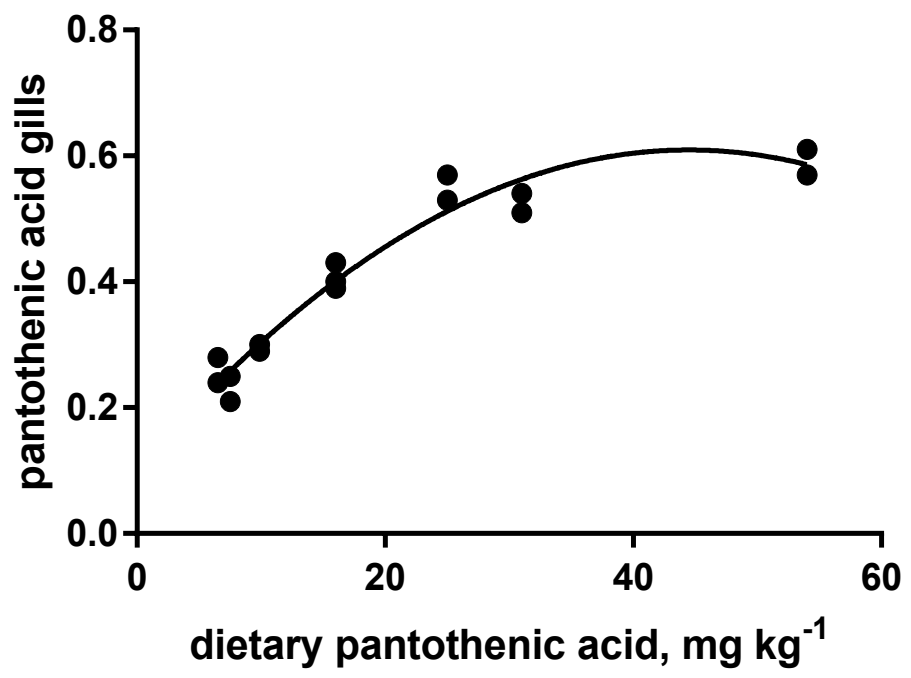

761

762

763 Figure 5. Pantothenic acid in gill tissue ( $y$-axis, $\mathrm{mg} \mathrm{kg}^{-1}$ ), and $\mathrm{x}$-axis with levels in feed; $\mathrm{p}<0.001, \mathrm{R}^{2}=0.95$;

764 second order polynomial. 